Policy Research Working Paper 1885

\section{Aid, Taxation, and Development}

\author{
Analytical Perspectives \\ on Aid Effectiveness \\ in Sub-Saharan Africa
}

Christopher S. Adam

Stephen A. O'Connell
Designing effective aid

programs requires accurately diagnosing problems. Under current donor efforts to promote democratization and institutional development, the shift from policy to institutional conditionality reflects an attempt by Africa's donors to recast the aid relationship from one that at best secures temporary policy changes to one that permanently alters institutions in favor of sustained growth and development.

The World Bank

Development Research Group

February 1998 
Policy Research Working Paper 1885

\section{Summary findings}

The design of effective aid programs depends on the diagnosis of the problem. To say that institutional failures are central to Africa's poor economic performance is not to repudiate early interpretations based on policy failures and capital shortages. Institutional failures produce policy failures that in turn produce capital shortages or the equivalent.

Adam and O'Connell focus on the core of the evolving (mainly external) diagnosis of the African development problem, making these main points, among others:

- Tax and taxlike distortions tend to be high and volatile in Africa. These influence the allocation of national wealth and can reduce both the level and productivity of domestic investment. The composition of domestic investment seems to be more important in explaining poor African growth than the level of domestic investment.

- Policy-generated uncertainty (underemphasized in the literature) can activate socially inefficient selfinsurance mechanisms that reduce growth. When leaders have substantial discretion about policy, as they do in most African countries, executive transitions become a major source of uncertainty.

- Patronage is heavily used in African systems of personal rule. Governments use distortionary taxes to finance transfers to politically powerful groups.
- A government that is captive to a favored group will trade off growth for transfers, if the group is small enough relative to the government's disposable resources. In such a case, conditional aid can be ineffective in spurring growth and investment, even when the potential gains from aid are great.

- Conditionality is required to secure the gains from aid when nonrepresentative political structures generate a conflict of interest between donors and recipient governments. When donors are in a strong bargaining position, conditionality agreements that mandate a reduction in distortionary taxes will also require that some part of lost revenues be made up by cuts in politically motivated transfers. But policy conditionality is difficult to enforce and even when perfectly enforceable is subject to the problem of aid dependency.

- To avoid aid dependency, donors must focus on conditionality that shifts the "no aid" point. Under current donor efforts to promote democratization and institutional development, the shift from policy to institutional conditionality reflects an attempt by Africa's donors to recast the aid relationship from one that at best secures temporary policy changes to one that permanently alters institutions in favor of sustained growth and development.

This paper - a product of the Development Research Group - is part: of the research project "Analytical Perspectives on Aid Effectiveness in Sub-Saharan Africa" (RPO 680-18). The study was funded by the Bank's Research Support Budget. Copies of this paper are available free from the World Bank, $1818 \mathrm{H}$ Street NW, Washington, DC 20433. Please contact Kari Labrie, room MC3-347, telephone 202-473-1001, fax 202-52.2-3518, Internet address klabrie@worldbank.org. February 1998. (46 pages)

The Policy Research Working Paper Series disseminates the findings of work in progress to encourage the exchange of ideas about development issues. An objective of the series is to get the findings out quickly, even if the presentations are less than fully polished. The papers carry the names of the authors and should be cited accordingly. The findings, interpretations, and conclusions expressed in this paper are entirely those of the authors. They do not necessarily represent the view of the World Bank, its Executive Directors, or the countries they represent. 


\title{
Aid, Taxation and Development: Analytical Perspectives on Aid Effectiveness in Sub-Saharan Africa
}

\author{
by
}

Christopher S. Adam* and Stephen A. O'Connell ${ }^{* *}$

*Queen Elizabeth House and Centre for Study of African Economies, University of Oxford, UK.

"Department of Economics, Swarthmore College, Swarthmore PA 19081, and Centre for Study of African Economies.

We are grateful to Robert Bates, David Bevan, Peter Boone, Paul Burnell, Alan Gelb, Ray Hopkins, Donald O'Connell, Mancur Olson, Jacob Svensson and Larry Westphal for valuable comments, to Trevor Dinmore, Karin Kimbrough and Jude Uzonwanne for excellent research assistance, and to the World Bank for financial support under the research project "Analytical Perspectives on Aid Effectiveness in Sub-Saharan Africa" (RPO 680-18). 



\section{Contents}

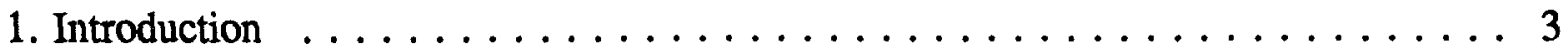

2. Five stylized facts $\ldots \ldots \ldots \ldots \ldots \ldots \ldots \ldots \ldots \ldots \ldots \ldots$

2.1 Slow growth and relatively low aggregate investment $\ldots \ldots \ldots \ldots \ldots$

2.2 Low private investment . . . . . . . . . . . . . . 5

2.3 Low ex post productivity of investment . . . . . . . . . . 6

2.4 High and volatile taxes and tax-like interventions $\ldots \ldots \ldots \ldots \ldots 6$

2.5 High levels of corruption and political uncertainty $\ldots \ldots \ldots \ldots \ldots 8$

3. Policy and growth in theory $\ldots \ldots \ldots \ldots \ldots \ldots \ldots \ldots$

3.1 Distortions and aggregate capital accumulation $\ldots \ldots \ldots \ldots \ldots$

3.2 Distortions and the composition of investment $\ldots \ldots \ldots \ldots \ldots \ldots$



3.4 Microeconomic channels of uncertainty $\ldots \ldots \ldots \ldots \ldots \ldots \ldots \ldots$

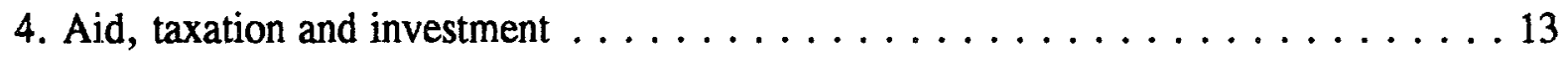

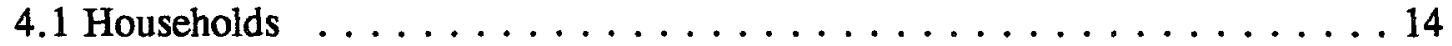

4.2 Government . . . . . . . . . . . . . . . . . . 15



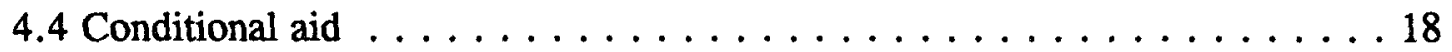

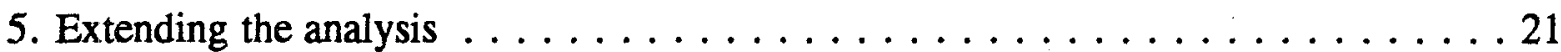

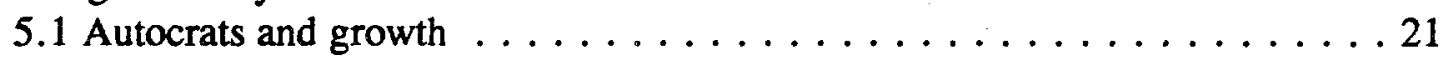



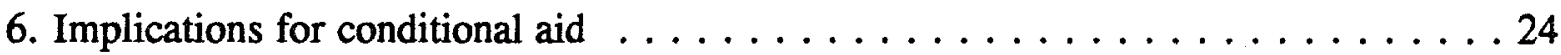

6.1 The Samaritan's Dilemma . . . . . . . . . . . . . . . . . 24

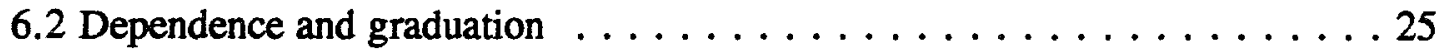

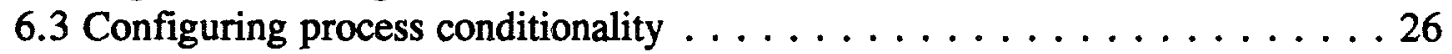

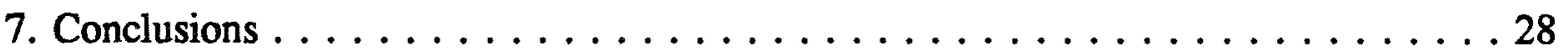

Appendix 1: Self-insurance, growth and taxation $\ldots \ldots \ldots \ldots 29$

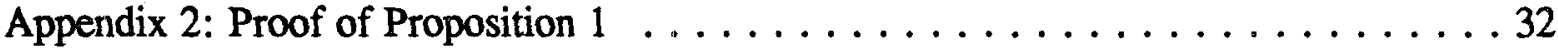

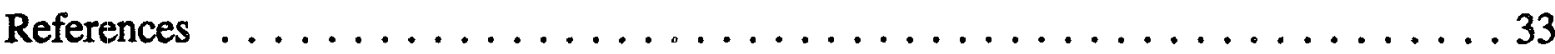





\section{Introduction}

Sub-Saharan Africa is the poorest and most aid-dependent region in the world. It was also the slowest-growing region in the period from 1960 to 1990 , contrary to what might reasonably have been expected given *substantial aid inflows and* the high returns to investment associated with capital scarcity. While achievements on social indicators are somewhat *more favorable* than those on economic growth, the overall contribution of aid to African economic development is now widely viewed as having been low.

Responding to economic stagnation and then to crisis beginning in the late 1970s, Africa's aid donors shifted from a "capital shortage" diagnosis of the African development problem to one that located capital scarcity in specific policy failures. Aid flows correspondingly shifted from low-conditionality project support to high-conditionality program assistance. The structural adjustment programs of the 1980 s focused primarily on redressing policy biases against agriculture and exports. By the late 1980s, however, the "policy failures" diagnosis had given way to deeper concerns about the adequacy of African political and economic institutions. Economic stagnation and low aid effectiveness came to be viewed as reflections of a more fundamental failure of the African state, particularly in relation to its own private sector. Consistent with this "institutional failures" diagnosis, the aid relationship in the 1990s has involved increasingly detailed economic and political monitoring and institutional intervention. Donors' concerns about the central role of institutions have if anything been heightened by the wave of democratizing changes that began to sweep Africa in the early 1990s.

Each diagnosis of the African development problem has encompassed the one that preceded it and in the process invalidated the set of donor strategies that previously represented best practice. It is too early to tell what the next diagnosis will add. One way to get ahead of donor perceptions, however, is to develop analytical models that are true to these perceptions and therefore capable of subjecting them to rigorous scrutiny. In this paper we make a beginning by sketching out some empirical and analytical underpinnings of the evolving aid diagnosis in Africa. We begin by summarizing stylized facts about economic performance and the policy environment in Africa. Synthesizing these observations with basic insights from the growth theory and political economy literatures, we lay out the formal mechanisms of an argument familiar from the literature on African political economy: that many African governments have *..* sacrificed broad-based economic development for more venal objectives. We focus in particullar on the use of tax and tax-like interventions to support politically-motivated transfers, subsuming under the heading of "taxes" a wide range of the most important distortions identified in the literature. We then draw on Boone (1996) and Olson and McGuire (1996) to construct an economy in which capital shortages are driven by policy failures which are in turn imbedded in the recipient's political economy. The model is designed to capture the main features of the earlier discussion and therefore to provide an effective vehicle for examining the effects of external aid and the role and limitations of conditionality. The analysis lends concreteness to the 'institutional failures' diagnosis and a surface plausibility to the increasing use of political and institutional interventions by donors. Its limitations are important, 
however. In part they reflect those of the broader literatures on political and economic institutions and particularly institutional change. In part, however, they reflect weaknesses or 'vain hopes' in donor perceptions and practice. In a concluding section we discuss the implications of the analysis for conditionality and suggest directions for further research.

It is important to acknowledge at the outset that we do not attempt any sophisticated modeling of donors in this paper. We treat donors as a single entity whose motivation is to enhance economic growth in the recipient country. ${ }^{1}$ While the evidence does not suggest a dominant role for pure altruism, donors may be led to a concern for economic development on purely selfish grounds, if there are negative spillovers to economic distress. More importantly, our main purpose is to examine the rather unanimous critique of recipient country political economy by the donor community.

\section{Five stylized facts}

Early critics of foreign aid, most volubly Bauer and Friedman, argued that the conventional rationale for aid--that temporary foreign inflows would alleviate a capital shortage and permanently lift countries out of poverty--mis-diagnosed the development problem. ${ }^{2}$ If capital shortages were the essential constraint to development, they would be solved by private international capital inflows. Even "big-push" or other externalities could be handled by private markets, via interest rate guarantees from recipient country governments who internalized these externalities. These authors offered more complicated diagnoses of the development problem, in which the decisive shortages were of political and economic institutions, broadly construed to include not only organizations but cultural practices and behavioral norms. Shortages of physical and human capital were merely symptoms of these deeper constraints. With inadequate institutions, aid flows could be wasted. They could even be positively inimical to growth, by strengthening the hand of predatory governments against the claims of rival domestic constituencies (Ake (1993), Bauer and Yamey (1982)).

The evolution of the aid relationship in Africa has reflected the movement of these arguments from the margins to the center of the debate. The views of Bauer and Friedman now find strong echo not only amongst the donors but also in an emerging mainstream in African political economy. A dominant theme of this literature is that conflicts of interest between African governments and their own populations play a decisive role in explaining poor

\footnotetext{
${ }^{1}$ We therefore leave aside (a) agency problems internal to individual donors, and (b) conflicts of interest and coordination problems across major donors as disparate as the World Bank group, the European Union, ex-colonial bilateral donors like France and the UK, and other bilaterals like the Scandinavian countries and Japan. The scope for conflicts of interest has been much reduced, at least temporarily, by the end of the Cold War and the convergence of donors in favor of market-based reforms.

${ }^{2}$ The "capital shortage" orthodoxy was deeply influenced by the experience of post-war reconstruction in Europe and led directly to aid policies based on official resource transfers for capital projects (Nurkse (1953), Chenery (1967), White (1992)).
} 
economic performance (Bates (1981), Sandbrook (1986), Collier (1991), Widner (1994)). While the details vary widely, a majority of the mechanisms identified in the literature can be subsumed under the heading of tax and tax-like policies that create a hostile environment for domestic private investment. We therefore begin in this section by presenting a stylized empirical basis for the view that high and volatile taxes, including the tax-like effects of bureaucratic corruption and policy uncertainty, have held back growth in Africa. We organize the discussion around five stylized facts, dealing in turn with the level and composition of investment in physical and human capital, the structure of implicit and explicit taxation, *..* and the extent and sources of policy-induced uncertainty. Table 2.1 sumriarizes the comparative performance of the region, subject to the dual caveat that (a) Africa is an exremely heterogeneous region, and (b) these data do not capture improvments registered on many measures since the late $1980 \mathrm{~s}^{3}$. Where possible we use median values to reduce the sensitivity of cross-regional comparisons to outliers.

\subsection{Slow growth and relatively low aggregate investment}

Africa's economic performance has been extensively documented (for example, World Bank, 1989 and 1994). Our first observation is therefore the familiar one that African economies have tended to grow more slowly than other developing countries and to devote a lower share of their total expenditure to investment. The median growth rate of per capita income in sub-Saharan Africa declined steadily from around 1.5 percent per annum in the 1960 s to less than 1 percent in the 1970s. During the 1980s per capita incomes declined by approximately 0.28 percent per annum [Table 2.1, Col 1]. This contrasts most markedly with East Asia where the median annual growth rate averaged almost 4 percent from 1960 to 1989 , and Latin America and the Caribbean which grew at an average of 1.1 percent despite experiencing a much sharper reduction in per capita income in the 1980s.

In contrast, while the aggregate investment rate is below that of other regions, it has remained reasonably high and stable over the period [Col 2], rising from approximately 13 percent of GDP in the 1960s to over 20 percent in the 1970s and remaining at almost 18 percent in the 1980s. Measured as a share of total domestic spending, the comparison reflects large African current account deficits (financed in large part by aid inflows) and is correspondingly less favorable [Col 3]: for the period as a whole, the median investment-toabsorption ratio was roughly 15 percent in Sub-Saharan Africa, compared with 19 percent in Latin America and the Caribbean and over 20 percent in East Asian countries and the OECD.

With marginally faster population growth, relatively low investment has meant markedly slower capital deepening in Africa than in other regions [Col 4]. To put this in perspective, if we supposed that Africa entered the 1960 s with the same aggregate capital-labor ratio as East Asia, then by 1990 the median African economy would have been operating with less than half the capital per person than East Asia. To the extent that the initial capital-labor ratio in Africa

\footnotetext{
${ }^{3}$ Except where noted, the data reported in this section are computed from the cross-country data compiled by the World Bank growth project (see for example, King and Levine (1993)).
} 




Unless stated, all data are from King and Levine (1993).

(1) Agenor and Montiel (1995), Table 15.4.

(2) Elbadawi and Schmidt-Hebbel (1996), Table 2.3

(3) Dollar (1992).

(4) Segaiorage is defined as (Ht-Hi-1)/GDP where

$H$ is the monetary base and GDP is nominal GDP. It

can be decomposed into an inflation tax term, [dp/(1+dp)*b]

where $d p$ is the inflation rate and $h$ the real monetary base,

and a term capruing the growith in real money demand.

(5) Claessens and Naude (1993). 


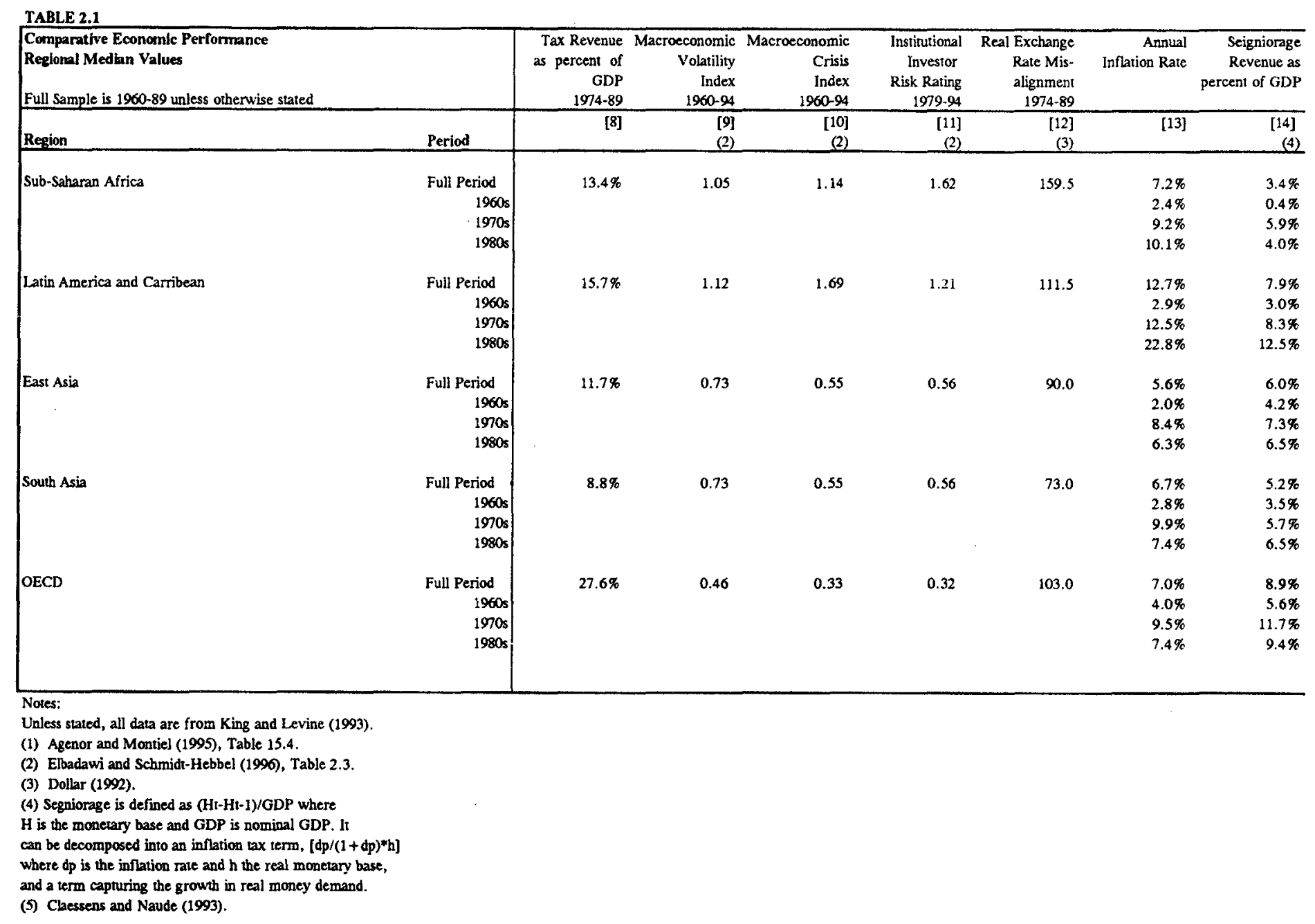




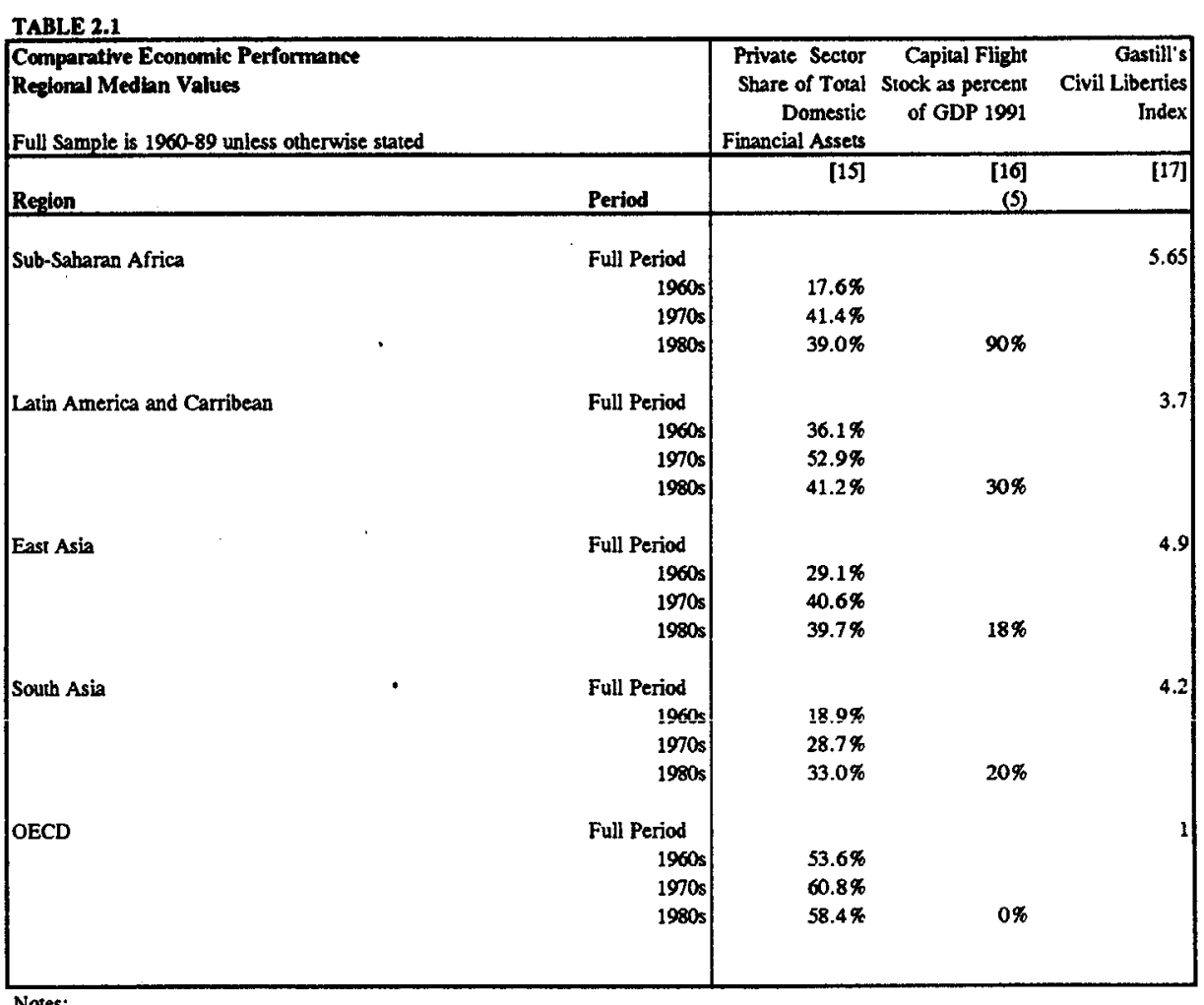

Notes:

(1) Agenor and Montiel (1995), Table 15.4.

(2) Elbadawi and Schmidr-Hebbel (1996), Table 2.3.

(3) Dollar (1992).

(4) Segniorage is defined as (Ht-Ht-1)/GDP where

$H$ is the monetary base and GDP is nominal GDP. It

can be decomposed into an inflation tax term, [dp/(1+dp)*h]

where $d p$ is the inflation rate and $h$ the real monetary base,

whe a is coptring

(5) Cleessens and Naude (1993). 
was lower than in East Asia, the true difference in capital intensity is correspondingly larger. The picture is only slightly less dramatic on the human capital side. ${ }^{4}$

\subsection{Low privgte investment}

Our second observation is that the level of private investment is very low in Africa, primarily because the public sector commands a larger share of total investment in Africa than elsewhere. Cross-country data cover only the central govemment share of investment [Col 5], and since these shares exclude other public sector investment they provide only a lower bound on the claim on total savings made by the pubiic sector. Even so, central government investment in Africa accounted for approximately 15 percent of total investment over the 1974-89 period, as compared with a share of approximately 5 percent in OECD and East Asian economies. 5 Comprehensive data for the share of investment accounted for by the state-owned enterprise (SOE) sector are not readily available, but Floyd et al (1984) provide period averages for the SOE sector's share in GDP and total fixed capital formation. Their data cover the period to approximately 1980, which corresponds to the apogee of the state sector worldwide, and therefore are likely to overstate the investment share of the sector. Notwithstanding this they suggest that in the OECD the SOE sector accounted for approximately 10 percent of GDP and a similar share of total fixed capital formation. Amongst non-African developing countries the SOE sector share of GDP was broadly similar, varying between roughly 8 and 12 percent; but the share of total investment was significantly higher, averaging 25 percent of GDP. In sub-Saharan Africa, however, the SOE sector accounted for approximately 18 percent of GDP on average and over 30 percent of total investment. To a first approximation we can take these shares as constant over the period from 1960-90 to 1990 and use them to partition total investment into public and private components. This is presented in Table 2.2 which suggests that comparing just private investment rates, a significantly lower share of total absorption is allocated to private investment in Africa and South Asia than elsewhere.

\footnotetext{
${ }^{4}$ A similar picture emerges if we look at investment in human capital. In 1960 schooling rates in Africa (measured in average years at each level of education per person) were approximately one third of the level enjoyed in other developing countries and about one fith of the OECD average. Over the three decades that have followed, education levels rose rapidly but with only limited convergence to allication attsinment levels elsewhere in the developing world. By 1985 almost 60 percent of the African population still had no schooling whatsoever, compared to 20 percent in South Asia and less than 3 percent in the OECD, while the level of per-cspita expenditure on ectucation remained significantly lower in Africa than elsewhere. The evidence broadly suggests that both the quantity and the qualify of education at each level remained lows than in other regions.
}

${ }^{5}$ African investment is much less intensive in equipment than elsewhere in the world, and correspondingly much more intensive in mon-quipment investment such as buildings and other forms of capital expenditure, including capital transfers to the parastatal sector (Devarajan et al, (1995)). 
Table 2.2 Distribution of total investment 1960-80 (as percent of absorption)

\begin{tabular}{llccc} 
Region & $\begin{array}{l}\text { Total } \\
\text { Investment }\end{array}$ & $\begin{array}{l}\text { Pubic Sector Share } \\
\text { of total investment }\end{array}$ & $\begin{array}{l}\text { Private } \\
\text { Investment }\end{array}$ & $\begin{array}{l}\text { Public } \\
\text { Investment }\end{array}$ \\
\hline Sub-Saharan Africa & 15.2 & & & \\
Latin America & 20.1 & 45 & 8.4 & 6.8 \\
East Asia & 23.8 & 35 & 13.1 & 7.0 \\
South Asia & 14.1 & 30 & 16.7 & 7.1 \\
OECD & 22.4 & 35 & 9.2 & 4.9 \\
\hline
\end{tabular}

Sources: Investment data from King and Levine (1993); data on public-private composition from Floyd et al (1984).

\subsection{Low ex post productivity of investment}

Observation number three is that aggregate investment in Africa is markedly less efficient than elsewhere. Crude measures of investment efficiency such as the incremental output-capital ratio (which measures the change in output per unit of investment, but without controlling for any other factors determining output growth) suggest that the productivity of African investment is approximately one quarter of that achieved in East Asia and half to two-thirds of that achieved by other developing countries [Col 6]. This pattern is corroborated by growth decompositions presented by Agenor and Montiel (1995), ${ }^{6}$ which suggest that while total factor productivity contributed an average of 1.3 percentage points of annual growth across all developing countries between 1971 and 1992 (and 2.6 percent for Asian economies), the corresponding contribution for Africa was only 0.2 percent [Col 7].

\subsection{Severe distortions and volatile macroeconomic policy}

We now shift to policy measures and the fourth observation that taxes and tax-like distortions have been high and macroeconomic policy has been volatile in Africa. Standard measures of the tax burden such as the tax to GDP ratio suggest a somewhat higher tax burden in than in other developing regions, with the exception of Latin America [Col 8]. More dramatic differences begin to emerge, however, when we control for the relative narrowness of the tax base in Africa and for the prevalence of tax-like interventions. We illustrate these points with a brief look at tax burdens facing international trade, agriculture, and the financial sector.

Taxes on international trade are administratively easy to collect and tend to make up a declining share of total revenues as per capita income rises (e.g., Gemmell (1993)). In African countries, such taxes accounted for an average of 35 percent of total revenues in the

\footnotetext{
${ }^{6}$ Agenor and Montiel (1995), Table 15.4, page 517. These calculations, based on IMF data, decompose the trend growth in GDP into components attributable to capital accumulation, growth in the labor force, and growth in total factor productivity.
} 
mid-1980s, as compared with 23 and 17 percent in Asia and Latin America/Caribbean (see World Bank (1988), p. 84). Given relatively minor cross-regional differences in the share of trade in GDP, this has meant high average tax rates on African trade. For the mid-1980s, for example, DeRosa reports an average import tariff of 29 percent across African countries, as against 20 percent for all developing countries; by the early 1990s trade liberalization had reduced tariffs worldwide but the median for Africa still exceeded that for other developing countries by 50 percent. ${ }^{7}$ African economies, particularly those outside the CFA zone, have also had greater recourse to quantitative restrictions on trade, further widening the regional disparity in effective tax rates. DeRosa (1992) finds that as late as 1987 some 90 percent of African imports, by value, were covered by non-tariff barriers (including foreign exchange rationing) outside of the CFA zone, compared to an average of 40 percent for all LDCs.

On the export side, real exchange rate overvaluation provides a measure of the implicit taxation of export-oriented production in favor of production for the home market. One standard measure is Dollar's (1992) index of real exchange rate distortion. Whereas in other regions actual real exchange rates have not deviated far from undistorted "equilibrium" values, controlling for income and trade structure -- and by this measure, the East Asian economies have maintained an undervaluation -- the median overvaluation in the sub-Saharan region has been on the order of 50 percent [ $\mathrm{Col}$ 12]. Large and persistent black market exchange rate premia provide independent evidence of overvaluation: outside the CFA countries, the median premium in Africa in the between 1980 and 1991 was 23.2 percent as against 18 percent for non-African developing countries. ${ }^{8}$ The overvaluation "tax" on exporters is additional to that implied by low producer prices paid by monopsony national marketing boards.

The available evidence also suggests that the agricultural sector has also faced an unusually heavy tax burden in some African countries. In a detailed study of 26 agricultural commodities, Schiff and Valdes (1991) found that a combination of export taxes, low puroducer prices, protection of manufactured inputs, and exchange rate overvaluation produced an average nominal protection rate of -52 percent for the three African countries in the sample (Cote d'Ivoire, Ghana and Zambia); the average for 15 other developing countries was -30 percent. $^{9}$

Financial repression provides a final example of the discouraging effects of tax-like policy. Measured by the change in the median ratio of M2 to GDP between the 1960s and the 1980s, the formal banking sector has grown twice as rapidly outside Africa as inside. High inflation has not generally been the culprit [Col 13]. Thus although some countries outside of the CFA

\footnotetext{
${ }^{7}$ Median average import tariff rates were 13.4 for 34 non-African developing countries and 18.7 for 15 African countries with available data for 1990-93 in World Bank (1997), World Development Indicators, Table 5.6.

${ }^{8}$ Data from Pick's Currency Yearbook, various years.

9 The calculated nominal protection rate is the sum of "indirect protection," which includes the effect of exchange rate overvaluation, the "tax due to industrial protection," and "direct protection," which accounts for direct taxes on agricultural activity.
} 
zone have relied heavily on the inflation tax, other features of policy have played a more decisive role in the lagging performance of the financial sector in Africa. Among these are heavy reserve requirements and other compulsory holding of government securities, often bearing below-market interest rates [e.g., Col 15, which shows the private sector share of total domestic credit]; partial expropriation of bank deposits as an instrument of monetary policy ${ }^{10}$; and widespread government control of interest rates and credit allocation (Caprio and Honohan (1991)). Together these have helped to produce financial systems that are substantially shallower than would be predicted given Africa's low level of income per capita. ${ }^{11}$ Low levels and slow growth of financial deepening have in turn severely limited the revenue from money creation [Col 14].

Our discussion has emphasized the level of distortions facing private economic activity in Africa. A final set of tax-like costs is associated with policy-induced uncertainty about the returns to alternative activities. Lacking direct measures of the volatility of the tax distortions over time and across countries, we rely here on measures of macroeconomic policy volatility and on the perceived riskiness of private investment in Africa. On the first dimension, Elbadawi and Schmidt-Hebbel (1996) find that African and Latin American economies have been characterized by relatively high levels of macroeconomic and financial policy volatility and relatively frequent macroeconomic crises compared to other $\mathrm{LDCs}^{12}$ [Cols 9 and 10]. Indicators computed by risk- rating agencies go even further, suggesting that Africa is perceived as being dramatically more risky than other regions [Col 11]. One consequence of this non-hospitable environment for domestic assets can be seen in capital flight: Claessens and Naude (1993) estimate that by the beginning of the 1990s the stock of flight capital from sub-Saharan Africa was equivalent to 100 percent of total 1990 GDP. Only the Middle-East economies have a higher stock of unrecorded financial and real assets held outside the domestic economy [Col 16].

\footnotetext{
${ }^{10}$ For example, in Ghana before the 1983 Economic Recovery Program, the People's National Democratic Council demonetized the Cedi 50 note and froze all bank accounts in excess of Cedi 50,000. Similar reforms have been implemented in Uganda and Zaire.

${ }^{11}$ The following regression using decadal averages suggests that $M 2$ is 15 percentage points of GDP lower in Africa than would be predicted on the basis of inflation and level of overall development (t-statistics -3.3,5.2,-6.8): M2/GDP = Decade effects $-0.25 *$ Inflation $+0.03 *$ Real GDP per capita $-0.15 *$ SSA,

Here SSA equals 1 for Sub-Saharan Africa and zero otherwise. "Decade effects" are decade-specific constant terms (not reported).

${ }^{12}$ Elbadawi and Schmidt-Hebbel measure ex post macroeconomic volatility as the equally- weighted sum of the variances of the public deficit to GDP ratio, the current account deficit-to-GDP ratio, the inflation rate, and an indicator of real exchange rate misalignment. Macroeconomic crisis is proxied by the one-sided deviation of macroeconomic policy indicators from a priori sustainable thresholds.
} 


\subsection{High levels of corruption and political uncertainty}

As a final observation, we note that African economies have, on average, been subject to relatively high levels of corruption and political uncertainty. Bureaucratic corruption is by no means an African phenomenon. Quantitative measures, however, suggest substantial scope for public predation on private economic activity in Africa. Using data for over 100 countries from the Economist Intelligunce Unit, Mauro (1995) constructs an index combining lack of corruption with perceived independence of the judiciary, and finds that 8 of the 9 African countries in the sample (the exception is Cote d'Ivoire) are concentrated in the bottom two quintiles. Knack and Keefer (1995) paint a similar picture using data on bureaucratic delays and the enforceability of contracts. The Gastill index of civil liberties, commonly used in the economic growth literature, measures civil liberties and political freedoms along a set of dimensions (e.g., the security of property rights, the freedom of the press); according to this index, African economies score poorly. Relative to the OECD score of 1 , the median index for Africa is 5.6, while that for Latin America, East Asia and South Asia is approximately 4 [Col 17].

Political uncertainty appears also to be relatively high in Africa. It is generally accepted that Africa is currently the most violent region of the world. However, in addition to being confronted by greater risks of total political collapse, many African economies are perceived as being subject to high levels of chronic political failure. Mauro (1995), for example, looks at subjective measures of political instability used in constructing country risk indexes. As with the corruption measure, 8 of the 9 African countries (with Cote d'Ivoire again the exception) are in the highest-risk quintile. This is notwithstanding the observation that until the early 1990s executive transitions were relatively infrequent in Africa; the region was characterized by a high incidence of military coups but by fewer overall changes in its largely authoritarian governments than in other developing region (Alesina and Perotti (1994)).

\section{Policy and growth in theory}

By the mid-1980s, the view that Africa's difficulties were primarily external had lost decisive ground to one that identified the primary causes in government policy. The latter view was bolstered in the early 1990s by cross-country evidence pointing to a substantially negative effect of macroeconomic policy distortions (Fischer (1993), Easterly $(1992,1994)$, Sachs and Warner (1995)) and volatility (Aizenman and Marion (1993), Gavin and Hausmann (1995), Ramey and Ramey (1995)) on long-run growth. Focusing on tax and tax-like policies, Figure 1 suggests a two-by-two classification of the ways in which policy reduces growth. The columns distinguish the distortion imposed by an intervention from the uncertainty created by the intervention; the rows distinguish effects on the level and composition of overall capital formation. The purpose of this section is to provide a brief review of the relevant economic theory. We begin with distortions (column 1), as a prelude to section 4 of the paper where we imbed these in a simple political economy model. We then discuss the growth effects of policy-induced uncertainty, a theme to which we return in section 5. 
Figure 1

Effects of policy on growth

Distortion Uncertainty

\begin{tabular}{|c|c|c|}
\hline $\begin{array}{l}\text { Level of } \\
\text { investment }\end{array}$ & $\begin{array}{c}\text { Sections } \\
3.1,3.3 \\
. .\end{array}$ & $\begin{array}{c}3.4,3.5 \\
.\end{array}$ \\
\hline $\begin{array}{c}\text { Composition } \\
\text { of } \\
\text { investment }\end{array}$ & $\begin{array}{c}3.2,3.3 \\
4\end{array}$ & $3.4,3.5$ \\
\hline
\end{tabular}


In what follows we will emphasize the negative effects of distortionary taxation, to the apparent exclusion of the spending side of government activity. If public spending is productive, of course, governments can in principle hold back growth as much by under-taxation as by over-taxation. A shortage of public infrastructure, for example, implies a high marginal productivity of public investment spending and therefore a high return on tax revenue. ${ }^{13}$ The return on tax revenue is also potentially high in "development trap" or endogenous growth models, where market imperfections typically provide a rationale for government intervention. But distortionary taxes, even when devoted to productive public spending, begin to reduce growth when pushed beyond certain levels (an elegant treatment is Cashin (1994)). Our emphasis therefore reflects the working hypothesis that tax rates exceed the levels justifiable by such spending. ${ }^{14}$ In section 4 , where we endogenize 'excessive' taxation, we use a model with the feature that taxes can potentially be too low as well as too high.

\subsection{Distortions and aggregate capital accumulation}

An increase in taxes can reduce national saving and growth either by redistributing income towards a government with high marginal propensity to consume, or, if marginal tax rates rise, by reducing the expected after-tax return to saving (or both). The first point is well illustrated by the neoclassical growth model of Solow (1956), in which the private sector saves a constant share of disposable income. ${ }^{15}$ Starting in a steady-state equilibrium with output and the capital stock both growing at the same rate as the labor force, an increase in the income tax rate transfers a portion of national income from the private to the public sector. If the public sector has a higher marginal propensity to consume, national saving falls, reducing investment and pushing the growth rate of the capital stock (and therefore of output) below that of the labor force. The message is simple: other things equal, a government that diverts a portion of current output into non-productive uses is likely to cause a reduction in national saving, and

${ }^{13}$ Hence the title of Kaldor's 1963 article, "Will Underdeveloped Countries Learn to Tax?".

${ }^{14}$ As partial evidence, we note again the relatively high levels of public investment in Africa (section 2.2). Moreover, spillovers and indivisibilities have been a staple, at least implicitly, of development programs ranging from big-push industrialization to integrated nural development to large-scale literacy and health intervention. If aid to Africa has failed, insufficient support to public spending is not an obvious culprit. Ultimately, of course, this is an empirical question, the evidence on which is currently unclear.

\footnotetext{
${ }^{15}$ A proportional tax is effectively lump-sum (and therefore non-distortionary) in this model, since labor supply is exogenous and saving does not depend on the after-tax real interest rate.
} 
therefore of capital accumulation and growth. ${ }^{16}$

To see the second point, we need a positive interest-elasticity of private saving, which means at least some degree of forward-looking behavior by the private sector. In this case, the anticipation of higher future tax rates on income from capital reduces the anticipated after-tax yield on investment. This reduces the interest rate investors are willing to pay for loanable funds. If saving is interest-elastic, aggregate saving falls; this brings down aggregate investment, and growth falls. We assume here that international capital mobility is relatively low; at the alternate extreme of perfect capital mobility, the relevant cost of capital would be determined in the world capital market and domestic investment would be independent of national saving. Taxes on the income from domestic capital would therefore alter the geographical composition but not the level of private investment and the capital stock. We treat capital flight as a composition effect below.

\subsection{Distortions and the composition of investment}

The dominance of low ex post productivity over low total investment in explaining low African growth (Section 2) suggests that the composition of African investment is a more fundamental problem for economic growth than its level. The likelihood that policy effects are primarily compositional is further buttressed by cross-country evidence suggesting an extremely low interest elasticity of saving at the low levels of per-capita income characteristic of much of Africa (Ogaki, et al (1996)). Moreover, compositional effects arising from non-uniform taxation of investment (either by origin or destination) are at the heart of the literature on African economic performance. The literature identifies policy structures whose ultimate effect is to favor public investment over private, foreign over domestic, urban over rural, nontraded over traded, and within the private sector, informal over formal (see inter alia Bates (1981), Elbadawi and Ndulu (1994), Ravenhill (1986), and Callaghy and Ravenhill (1993)). In all cases there is, with some oversimplification, a clear distinction between taxed and non-taxed forms of investment or capital.

Thus, private investment has received less supportive treatment than public investment in many African countries, even when public goods are not obviously involved; examples range from large-scale nationalizations of private enterprise to prohibitions on private ownership of rural land to the disproportionate share of formal bank credit received by parastatal enterprises engaged in the production or distribution of private goods. Public employment practices have

\footnotetext{
16 Alternative theoretical traditions in the growth theory literature differ in the duration of the growth effects studied here and below. In the neoclassical tradition (Solow (1956), Calss (1965), Diamond (1975)), a fall in the saving rate produces a temporary reduction in the growth rate. In endogenous growth models (surveyed in Bardhan (1995)), the same mechanism produces a permanent reduction in growth. The decisive issue here is the degree to which long-run growth is limited by non-reproducible ('fixed') factors of production. If (as in neoclassical models) growth is tied down by fixed factors, distortions affect the level of income per capita but not its long-run growth rate. If growth is not limited by fixed factors, distortions that affect the accumulation of reproducible factors (like capital) can affect the long-nu growth rate. In practice, given the very protracted adjustment periods of the neoclassical model, the difference is not likely to be important.
} 
distorted investments in specific human capital towards the public sector. ${ }^{17}$ Domestic investment has in many cases been discouraged relative to foreign investment, both directly by the greater prospect of confiscation or taxation, and indirectly by financial repression; this has resulted in capital flight. Investments in traditional export crops have been heavily taxed relative to urban investments in many countries, part of a broader urban bias that has raised the return to urban investments over that in rural investments, while inward-looking development strategies and the administrative ease of taxing international transactions have biased capital formation towards non-traded uses (including quota-protected industries where output is nontraded on the margin). Finally, the rapid growth of the informal sector has sometimes been attributed to the ability of this sector to avoid taxes or to exploit implicit subsidies created by government taxation of the formal sector.

The mechanism through which non-uniform taxation reduces growth is straightforward (Easterly (1992)). Differential tax treatment drives a wedge between the before-tax marginal products of capital in alternative uses, reducing the level of output generated by any given aggregate stock of capital. The fall in output then lowers aggregate saving at the original saving rate, slowing the rate of capital accumulation. If investors are forward-looking, there may be an additional effect on saving from a change in the after-tax marginal product of capital. The growth rate therefore falls.

\subsection{The time consistency problem}

Growth effects that operate through the return to saving or the relative return on alternative investments rely on expected future tax rates rather than on current distortions. Governments therefore have an incentive to announce low future tax rates in the hope of generating high and productive investment and a large tax base. As the literature on time consistency points out, however, the government's capacity to alter tax rates after the private sector has accumulated taxable assets renders such announcements intrinsically non-credible. As long as

non-distortionary taxes are limited and investment is at least partially irreversible, high rates of capital taxation will seem attractive ex post. Anticipating this, the private sector will substitute current consumption for savings and (in a composition effect) switch its investment away from readily taxable forms of capital towards those which are less taxable. These responses are self-confirming: faced with a narrow tax base, the government will indeed find it optimal to levy high tax rates ex post. Growth therefore falls, to a greater degree the larger the disparity between social rates of return on immobile, easily taxable assets and other forms of investment.

The problems of commitment and time consistency confront all governments. Political structures that generate predatory government behavior, however, can exacerbate an existing time consistency problem or even create one where one would otherwise not exist. In section

\footnotetext{
17 See for example Collier and Garg (1996) who find that employment, promotion, and access to publically funded professional training in the public sector in Ghana is determined by kinship ties rather than by performance or other indicators of productivity.
} 
4, for example, we study a government that is non-representative in the sense of catering to the interests of a subset of the population. Whereas even a modest administrative cost will deter a fully representative government from taxing installed capital for the purposes of effecting transfers, a government that is non-representative in our sense will have an incentive, ex post, to renege on its announced policy in order to make transfers to the favored group. The higher the transactions costs associated with taxation and transfers, the less representative the government needs to be to ensure that it will not make transfers. But unless transactions costs are high and borne by the favored group, a non-representative government will require additional mechanisms to bind it to ex ante promises. Collier (1991) argues forcefully that the absence of effective agencies of restraint in post-independence Africa accounts for the persistence of a capital-hostile policy environment. ${ }^{18}$

\subsection{Microeconomic channels of uncertainty}

We now turn to the relationship between policy-induced uncertainty and the level and composition of investment [the second column of Figure 1]. The investment and growth literatures identify risk aversion of investors and irreversibility of investment projects as distinct and fundamental channels through which uncertainty about the returns on investment may affect growth. Consider, for example, a firm facing a mean-preserving spread in the distribution of future output prices. If the firm is risk-neutral and investment is costlessly reversible, the convexity of the profit function in prices means that greater uncertainty increases expected profits. ${ }^{19}$ Investment therefore rises. But if either assumption fails, the rise in uncertainty may reduce investment. Sufficiently great risk aversion does this by overcoming the convexity of the profit function, so that the firm's expected utility falls with the rise in uncertainty even though expected profits rise. Irreversibility reduces investment either by increasing the option value of postponing the investment or by increasing the probability that the firm will prove, ex post, to have misallocated its investment. ${ }^{20}$

The presumption in favor of composition rather than level effects is, if anything, stronger

\footnotetext{
${ }^{18}$ The evohution and/or development of such commitment mechanisms has been extensively studied in the recent political science and new institutional economics literature (see Rodrik and Zeckhauser (1987), Kotlikoff et al, (1988), Persson and Tabellini (1994), Soskice et al (1992), North and Weingast (1989) and McGuire and Olsen (1996)).

${ }^{19}$ The profit function is strictly convex in the output price as long as the firm can adjust some dimensions of its production plan after observing the price. These adjustments allow the firm to capitalize on favorable price movements and limit the damage of unfavorable ones, so that a mean-preserving spread in future prices raises average profits.

${ }^{20}$ The first of these channels has been the dominant one in the theoretical literature on irreversible investment (see Dixit and Pindyck (1993)). The second bears a strong resemblance to the mechanism through which non-uniform taxation of capital income generated growth effects in Section 3.2; its effects operate more strongly through the ex post productivity of investment than through the level of investment.
} 
with respect to uncertainty than with respect to the (average) level of distortions. The central argument is a general-equilibrium one: an increase in uncertainty about after-tax future incomes actually increases aggregate saving if risk-averse households have a precautionary saving motive. This will dominate the fall in investment demand if the interest elasticity of saving is sufficiently low. And while the long-run effects of uncertainty are unclear in the case of irreversible investments, greater uncertainty clearly shifts investment away from irreversible capital in the short run. ${ }^{21}$ This compositional effect is likely to persist over the empirically relevant horizon. Some evidence that uncertainty differentially discourages irreversible investments in Africa is provided by Pattillo (1996) using firm-level data from the Ghanaian manufacturing sector, and by Fielding (1996), using sectoral investment patterns in South Africa.

A potentially important set of compositional effects that rely on risk aversion come under the heading of 'self-insurance' mechanisms. The literature on rural institutions gives a central role to risk aversion in explaining the behavior of peasants, a group that makes up a larger share of producers in Africa, on average, than in any other region in the world. But while the thrust of this literature has been to emphasize the positive role of rural institutions like rotating saving/credit clubs or interlinked land tenure and credit arrangements in coping with income fluctuations ex post, Morduch $(1994,1995)$ and others have recently emphasized that when ex post mechanisms are limited, households will trade off expected profits for a reduction in income variability ex ante. In this view, a peasant household will choose safer, lower-yielding activities in order to limit income variability to what is readily insurable by available--but costly and imperfect--ex post mechanisms. The micro-econometric evidence that exists is almost entirely built on the ICRISAT data for a set of Indian villages, but self-insurance mechanisms are likely to be at least as important in Africa as in India (see, for example, Berry (1993)). They imply that greater uncertainty, even in the absence of irreversibilities, can lower aggregate growth. Appendix I formalizes this point using a stylized endogenous growth model. Peasants choose between a safe but low-yielding activity and a risky but higher-yielding one. If the relevant risks are idiosyncratic and therefore diversifiable, the social optimum has all peasants choosing the risky activity. In the absence of insurance markets, however, peasants self-insure by choosing the safe but lower-yielding project, lowering aggregate growth and welfare.

\subsection{Government policy and uncertainty}

Tax and tax-like policies can adversely affect privately perceived economic risks either by undercutting institutions designed to handle risk or by directly creating uncertainty about the after-tax returns on investment. The first channel emerges naturally from the literature on financial repression. The emphasis of that literature has been on interest rate controls and other

\footnotetext{
${ }^{21}$ With irreversible investment, the effect of increased uncertainty on the firm's long-run capital stock is theoretically ambiguous. Increases in uncertainty lower a competitive firm's investment in the short run but, through a 'lock-in' effect, may actually raise its expected capital stock in the long run (Abel and Eberly (1993)).
} 
distortions that affect the quantity and quality of investment along the lines of Sections 3.1 and 3.2. The associated disintermediation, however, can slow the development and impair the risk-handling capacity of the formal financial sector as a whole, throwing the private sector back onto socially inefficient self-insurance mechanisms of the type described above. The empirical evidence on the importance of financial deepening for growth (King and Levine (1993)) is consistent with either channel or both.

Impairment of the risk-sharing function of financial institutions has not generally been emphasized in accounts of African economic performance. A more prominent but often implicit theme has been that governments actually create economic uncertainty (e.g., Berry (1993)). The theoretical literature suggests a variety of potentially relevant channels. In Khan and Ul Haque (1985), for example, domestic assets are subject to the possibility of nationalization. Individuals know the probability of nationalization but have no way of influencing its occurrence. They handle this risk by financing high-yielding domestic investments abroad and at the same time placing gross saving in low-yielding but safe foreign accounts. The uncertainty surrounding nationalization is important here; in the Khan-Ul Haque model, individuals would not diversify abroad if they faced a fixed tax on domestic assets that equalled the expected tax rate associated with nationalization. Similarly, Rodrik (1989) shows how rate-of-return uncertainty generated by the possibility of reversal of trade liberalizations, exchange rate reforms, or other policies affecting sectoral relative prices discourages irreversible investment in a manner equivalent to an increase in the average tax rate. Appendix I provides a third potential example, in which risk-averse peasants (or other firms) choose between two safe and reversible investments. One strictly dominates the other in the absence of taxes, but being immobile, is taxable while the low-yielding alternative is not. Then in a no-tax equilibrium, the high-yielding asset dominates and the private sector does not diversify. By contrast, a stochastic tax/subsidy rate, even with a mean of zero, will lead to socially inefficient diversification.

It is worth noting that the risk-creating features of the African policy environment offset a natural capacity of proportional tax systems to diversify idiosyncratic risks and shift systemic risk to the public sector (Atkinson and Stiglitz (1980)). Domar and Musgrave (1944) noted that when tax rates are non-stochastic, an increase in the (proportional) tax rate on income from a risky, high-return asset shifts a greater portion of the underlying rate-of-return risk to the government, increasing private incentives for risk-taking. While this reasoning has not been applied in the developing country literature (Ahmed and Stern (1988)), it raises the possibility that a tax increase that in the absence of uncertainty would have made the private sector worse off may actually increase growth and welfare. ${ }^{22}$

\footnotetext{
${ }^{22}$ Private risk-taking rises because risk-averse investors have an incentive, ignoring the wealth effect of the higher tax rate, to trade off some of the lower risk for a higher average return on their overall portfolio. The theoretical relationship between taxes and risk-taking is not robust across alternative specifications of the portfolio problem, however; see for example Atkinson and Stiglitz (1980, Lecture 4) and Sandmo (1985). Results tend to become ambiguous when the safe asset has positive return, when there are many risky assets, or when there is no loss offset, so that negative returns on the risky asset do not reduce the investor's overall tax liability.
} 


\section{Aid, taxation and investment}

The thrust of the previous two sections has been to establish that tax and tax-like policies can and do impair economic performance. As donor policy mobilized behind a 'policy failures' diagnosis in the late 1970s and early 1980s, political scientists were developing arguments that embedded these failures in the systems of personal rule that dominated African politics until the 1990s. Bates (1981), Sandbrook (1986) and others saw the heavy use of patronage, the discouragement of restraining institutions, and the emasculation of competing centers of political power as 'rational' strategies of African leaders in the context of weak political legitimacy and tenuous bureaucratic control. A central theme of these contributions was the existence of a fundamental conflict of interest between African governments and their own private sectors:

"Quite apart from philosophic predisposition, however, recent experiences in Africa and elsewhere make it clear that the preferences of governments often bear little correspondence to any idealization of the public interest. Rather, governments engage in bureaucratic accumulation and act so as to enhance the wealth and power or those who derive their incomes from the public sector; they also act on behalf of private factions, be they social classes, military cliques, or ethnic groups. They engage in economic redistribution, often from the poor to the rich and at the expense of economic growth. These are central themes in policy formation in Africa and their prominence serves to discredit any approach based on a conviction that governments are agencies of the public interest." [Bates (1996), p 17].

In this section we incorporate this conflict of interest in an intertemporal model relating tax interventions to growth. Since the uncertainty channels of policy are less settled both empirically and theoretically, our model focuses on the 'distortion' effects discussed above. We build in a central role for composition effects by allowing households to choose between a high-yielding but taxable investment and a lower-yielding investment that escapes the tax net. The resulting structure (which fits in the southwest box of Figure 1) captures key features of the preceding discussion and is simple enough to allow a formal exploration of aid and the role of conditionality.

To characterize the underlying conflict of interest, we follow Boone (1996) and Olson and McGuire (1996) in assuming that the government is fully captive to an interest group that comprises a fraction $0 \leq f \leq l$ of the domestic population. By treating the size of this interest group as a parameter, we can trace out the consequences of personal rule from the least to the most representative -- in effect, from Mobutu to Mandela. We treat $f$ as predetermined, leaving to later discussion the process whereby the leader identifies his own interests with that of the favored group. As in Boone (1996), the government has the option of levying distortionary taxes in order to make transfers to the favored group. To reflect the reality of most African fiscal systems, we assume that non-distortionary forms of taxation are unavailable. 
To capture necessary and legitimate forms of public expenditure, we introduce a second parameter, $G$, measuring the level of government spending on essential public goods (such as security from external military threat). Absent foreign aid, the implied 'revenue imperative' means that even a fully representative government will engage in distortionary taxation. By treating $G$ as a parameter, we have a simple way of capturing the difference between (for example) Nigeria--with oil wealth representing substantial command over public goods per capita, and with few external security concerns--and Malawi--with a subsistence economic base and (neighboring not only South Africa but also Mozambique and Zimbabwe) a history of serious regional security concerns. The level of $G$ could be endogenized without changing the analysis. $^{23}$

\subsection{Households}

We focus on a two-period analysis in which households receive an income $Y$ in the first period of life and choose an investment portfolio to maximize a time-separable utility function defined over present and future consumption. Total investment is split between a tax-free project that yields $R>0$ per unit and a taxable high-yielding project that produces future output $g\left(K_{H}\right)$, where $g^{\prime}>0, g^{n}<0$ and $g^{\prime}(0)>R$. Using upper- and lower-case letters to denote firstand second-period values, respectively, the maximized value of household utility is given by

$$
\begin{array}{ll}
V(t, z ; E) \quad=\quad \begin{array}{l}
M a x \quad u(C)+\beta u(c) \\
\left\{K_{H}, K_{L}\right\}
\end{array} \\
\text { subject to } & C=Y-\left(K_{H}+K_{L}\right) \\
\text { and } & c=(1-t) g\left(K_{H}\right)+R K_{L}+z,
\end{array}
$$

where $C$ and $c$ are consumption in the two periods, $O<\beta \leq 1$ is the discount factor, $t$ is the tax rate on output from the high-yielding project, and $z>0$ is a non-negative transfer from the government (lump-sum taxation is ruled out). We will assume that although the household cannot borrow, this constraint is not binding.

The first-order conditions in (1) imply $(l-t) g^{\prime}\left(K_{H}\right)=R$, which yields an investment function of the form

$$
K_{H}^{*}=K_{H}[R /(1-t)], \quad K_{H}{ }^{\prime}<0 .
$$

The high-yielding investment is therefore a declining function of both the tax rate and the return on the non-taxed investment.

Figure A1 shows the response of a household to an increase in the tax rate. Investment in

\footnotetext{
${ }^{23}$ What matters is that the financing of $G$ require some level of distortionary taxation. See Olson and McGuire (1996) for analysis with endogenous G (but without foreign aid).
} 
Figure A1

\section{An increase in the tax rate on output from the high-yielding project}



An increase in the tax rate rotates the set of feasible consumption patterns from Ebd to Eb'd'. The optimal consumption choice shifts from point 1 to point 2 . 
the high-yielding asset falls, to a level at which its after-tax yield is again equal to the yield on the non-taxed investment. This shrinks the government's tax base and reduces the average quality of investment. Aggregate investment $\left(K_{H}+K_{L}\right)$ rises, however, since households increase saving in order to smooth out the fall in future disposable income. ${ }^{24} \mathrm{An}$ important property of the investment function (2) is that investment in the taxable asset is independent of both $Y$ and $z$. This means that the government's tax base is independent of the distribution of either current income or future transfers, a feature that simplifies the analysis considerably. ${ }^{25}$

\subsection{Government}

The government maximizes the utility of a select subset of the population, as in Boone (1996). With households distributed uniformly over the unit interval, we can think of the favored group as constituted by any subset with probability mass $0 \leq f \leq 1$. The government has two instruments at its disposal: the distortionary tax $t$, which is non-selective in the sense that all households bear it, and the selective transfer, $z$, which is enjoyed only by the favored group. The government must also meet the fixed public spending requirement of $G \geq 0$. Since our focus is on distortions from expected future taxation, fiscal interventions and foreign aid all take place in period 2. We defer a discussion of time consistency issues to the end of the section, assuming for the present that the government can credibly set its tax and transfer rates in advance.

The government therefore chooses $t$ and the aggregate level of transfers, $T=f z$, in period 1 to solve the problem:

$$
\begin{array}{ll} 
& \begin{array}{l}
M a x \\
\{t, Z\}
\end{array} \\
\text { subject to } & T+G=\operatorname{T}(t / f, Y) \\
& T \geq 0,
\end{array}
$$

where $A$ is the inflow of aid in period 2. Equation (3.1) is the government's budget constraint. It states that tax revenues plus aid are used to finance either transfers or public spending. We assume that aid does not cover required spending, so that the "net spending requirement" $G-A$

\footnotetext{
${ }^{24}$ Disposable future income falls due to higher taxes and a lower before-tax yield on the household's total investment portfolio; future output, in contrast, may rise or fall depending on whether the increase in total investment overcomes the deterioration in the average yield.

25 This aggregation property relies on the linearity of the tax-free production function and is therefore not general.
} 
is positive. Since inequality (3.2) rules out lump-sum taxes, this implies that some degree of distortionary taxation $(t>0)$ is inevitable.

The solution to (3) is illustrated in Figure A2, where we show the government's budget constraint and a set of indifference curves corresponding to its objective function $V$. Given the value of $G-A$, the budget constraint is a Laffer curve relating aggregate transfers to the tax rate on income from the high-yielding project. A rise in the tar rate increases the feasible level of total transfers, up to the point where the tax-elasticity of output from the high-yielding project, $\eta(t)$, is unity:

$$
\eta(t)=-\operatorname{tg}^{\prime}\left(K_{H}^{*}(t)\right) / g\left(K_{H}^{*}(t)\right)=1
$$

Beyond this point, further increases in the tax rate reduce revenue and thereby total transfers. The government's net spending requirement is a parameter of this Laffer curve: a rise in $G-A$ reduces feasible transfers dollar-for-dollar, shifting the curve vertically downwards. Changes in $f$, in contrast, leave the curve unchanged, since the investment function is identical for the favored and non-favored groups.

The government's indifference curves show combinations of $t$ and $T$ that yield constant indirect utility for the favored group. They are upward-sloping because taxes reduce utility while transfers raise it. They are also concave, but the solution is unique if they are less concave than the Laffer curve, a reasonable property that we will assume in what follows. ${ }^{26}$ Since the high-yielding investment function does not depend on transfers, the indifference curves are vertically parallel. Changes in the political economy alter their shape, however: a fall in $f$ concentrates a given transfer $T$ on a smaller group, flattening out the indifference curves.

Ignoring the nonnegativity constraint (3.2), the solution to (3) takes place at the point of tangency between the Laffer curve and a government indifference curve. The optimal choice of $t$ satisfies the condition

$$
\eta(t)=1-f, \text { where } \eta(0)>0 \text { and } \eta^{\prime}(t)>0 \text {. }
$$

For a non-representative government $(10 w f)$, this generates an interior solution for both $t$ and $T$ (point 1 in Figure A2), with a tax rate high enough to finance transfers to the favored group. As the size of this group shrinks towards zero, the indifference curves rotate in a clockwise

\footnotetext{
${ }^{215}$ By the envelope theorem, $\partial V / \partial t=-\beta U_{23}\left(K_{N}\right)$ and $\partial V / \partial T=(1 / f) \partial V / \partial z=\beta U_{2} / f$, implying that $d T / d t=$ $f g\left(K_{f y}\right)$ along an indifference curve. The indifference curves are therefore concave, since $d^{2} T / d t^{2}=f g^{\prime}\left(K_{f \nu}\right)>0$, raising at least the possibility of multiple equilibria or failure of the first-order conditions. These problems do not arise, however, if we choose the production function $g\left(\mathbb{K}_{k J}\right)=A \mathbb{K}_{H}{ }^{a}$ for $0<a<1$, in which case the indifference curves and Laffer curve appear as in Figure A2.
} 
Figure A2

The government's choice of $t$ and $T$



As $f$ varies from 0 to $f^{9}$ G-A), the optimum at point 1 moves from point 2 to point 4 . Further increases in $f$ move the tangency towards point 3 , but the optimal policy remains at point 4 . 
direction and the equilibrium moves to the top of the Laffer curve, where $\eta=1$ (point 2). A perfectly representative government, in contrast $(f=1)$, wants to avoid the social cost of distortionary taxation. If lump-sum taxation were possible, this government would choose point 3, where $\eta(t)=t=0$ (its indifference curves being steeper than the Laffer curve at all tax rates). With lump-sum taxes impossible, this government chooses point 4 where the tax rate is just large enough to meet the exogenous public spending requirement.

The most interesting case is that of the government that is not fully representative $(f<I)$ but nonetheless does not make transfers. Proposition 1 states that as long as the net spending requirement is positive, a range of such governments will exist. The government need only be "sufficiently representative" in order to choose zero transfers (Boone (1996), Olson (1994)).

\section{Proposition 1: The "sufficiently representative" government.}

If $G>A$, there is a cutoff value $f^{c}<1$ above which the government will choose not to make transfers. All governments with $f<f^{c}$ will make transfers, with the size of the transfer (and accompanying tax rate) inversely related to the size of the favored group.

Proof: See Appendix.

This proposition is intuitively appealing. With a positive net spending requirement, distortionary taxes are strictly positive even when transfers are zero. The marginal social cost of tax revenue is therefore strictly greater than one, and the favored group faces a substantial share of this cost. A rise in aggregate transfers therefore fails a cost-benefit test, even accounting for the concentration of marginal benefits. ${ }^{27}$ If the favored group is small, in contrast, the distortion is largely borne by the non-favored group, and a small increase in the tax rate generates a large enough transfer per member of the favored group to justify the increase. ${ }^{28}$ On the margin, a rise in $f$ increases both the tax rate and aggregate transfers if the latter are already positive.

In the following sub-sections we use the model to examine the effect of unconditional and conditional aid on taxes and transfers, and therefore on investment and growth. Before doing so, however, note that the model provides an interpretation of the "developmental state" and the relative influences of exogenous forces and internal political economy in generating it. As long as $f>f^{c}$, the government "gets the prices right" -- in this case, avoiding excessive distortion of the relative yields on alternative forms of capital -- and avoids transfers to special interests. The transfer cutoff can therefore be thought of as the level of representation above which a government internalizes the general interest in high-yielding investment and growth. A

\footnotetext{
${ }^{27}$ If the net spending requirement were zero, any government that was not fully representative would find it worthwhile to impose a small distortionary tax.

${ }^{28}$ We are treating $f$ as predetermined here. Note, however, that free-rider problems and other costs of collective action create a strong presumption that $f$ is small.
} 
government need only be "sufficiently" representative, according to Proposition 1, to constitute a developmental state. Moreover, the cutoff level is a declining function of the net spending requirement. Other things equal, transfers become a more expensive luxury as $G-A$ rises, and they will emerge only if the favored group faces a small enough share of the marginal costs and enjoys a sufficiently concentrated marginal benefit. The analysis therefore implies that adversity -- for example, in the form of an external military threat that generates a high $G$-- is more likely to produce a developmental state than ease, holding constant the historical, cultural and economic determinants of $f$.

Proposition 2: External determinants of the developmental state.

\begin{abstract}
A fall in G-A increases the level of representation that is required to generate zero transfers.
\end{abstract}

Proof: The cutoff value of $f$ is given by $f^{c}=1-\eta(t)<1$, where $t$ solves $t=$ $(G-A) / g(t)$ (see Appendix). Since $t$ is an increasing function of $G-A$ and $\eta$ is an increasing function of $t$, we can write $f^{c}=f^{c}(G-A)$, with $f^{c \prime}<0$.

\title{
4.3 Unconditional aid
}

We now turn to a more complete analysis of the effect of (anticipated) aid, starting first with unconditional aid. Under our assumptions, an increase in aid shifts the tangency point of indifference curves and the Laffer curve vertically upwards. The response to aid inflows therefore takes the extreme form of Boone (1996). A sufficiently representative government reduces taxes and retains zero transfers. For this government, aid crowds in productive forms of domestic capital formation by reducing distortionary future taxation. A government that is already giving transfers, in contrast, uses an increase in aid to increase transfers dollar for dollar, leaving the tax rate unchanged. These points are illustrated in Figure A3, where we begin with a net spending requirement that is large enough, given $f$, to generate zero transfers (point 1). Small increases in aid (represented by the arrows) go first into reductions in the tax rate, and then into higher transfers.

The non-representative but non-redistributing government (moderate $f$ ) again provides an interesting case. For this government, small increases in aid reduce distortions, but a large enough increase also justifies the initiation of transfers to the favored group. This occurs while distortionary taxation is still positive. It is illustrated in Figure A3 by a jump from point 1 to a point like 3. 
Figure A3

The effect of unconditional aid inflows

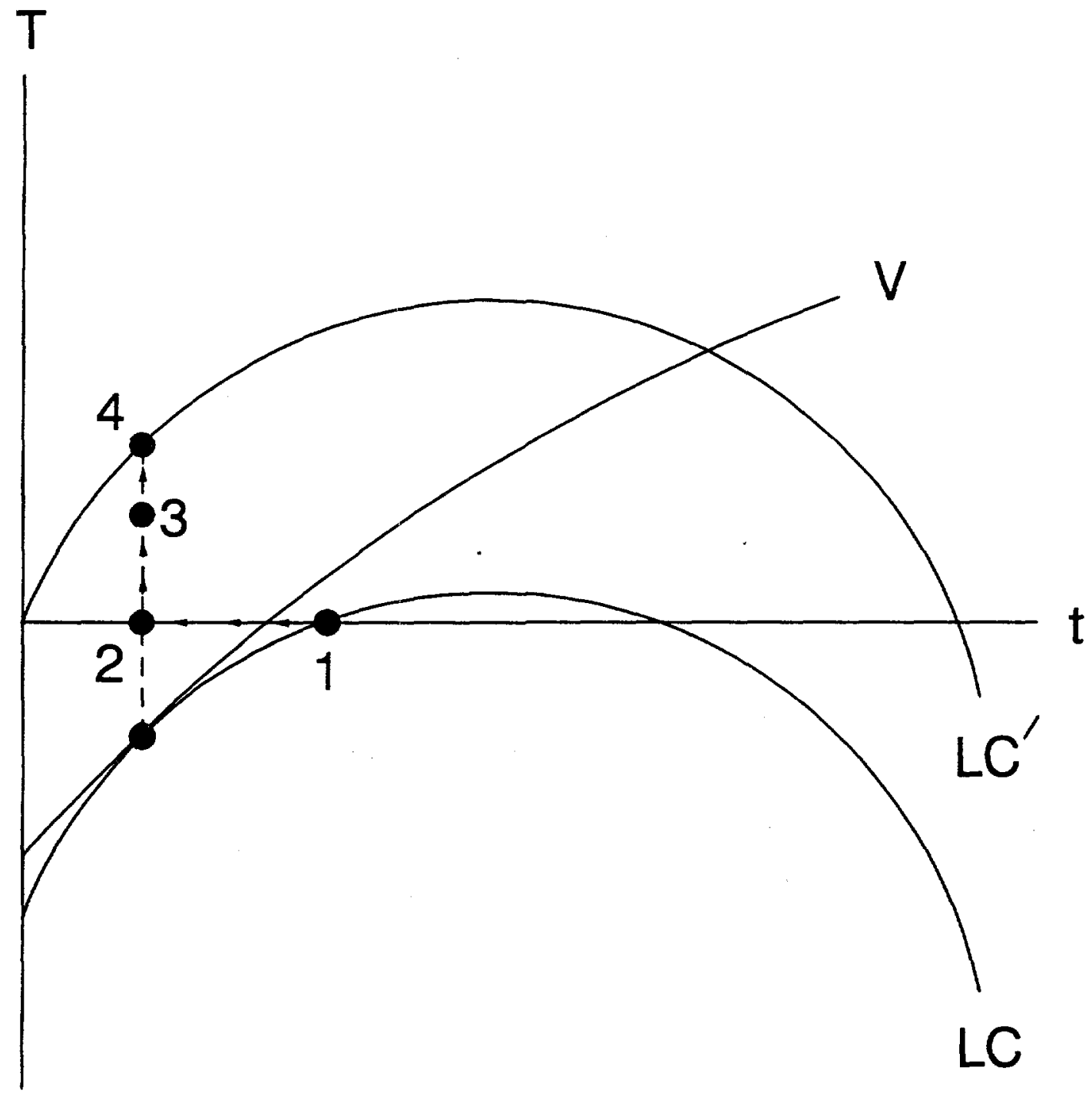

Given $\mathrm{G}$, a rise in A shifts the Laffer curve upwards. For a government initially giving zero transfers (point 1 ), aid inflows first reduce the tax rate, to point 2 , and then go fully into transfers, through point 3 to point 4 where $A=G$. 
Proposition 3: The effect of aid.

For $f \geq f^{c}$, a small increase in aid reduces the tax rate without initiating transfers. For $f<f^{c}$, in contrast, any increase in aid, whether small or large, goes fully into transfers. Moreover, for any government, there is some amount of aid above which transfers will be initiated. As long as the government is not fully representative (so that $f<1$ ), this will occur while the tax distortion is still positive (i.e., before aid pays for all of required public spending).

The analysis of unconditional aid is easy to summarize. For a "developmental state", unconditional aid reduces distortions, thereby delivering benefits greater than those attached simply to a consumption transfer. But if this state is not fully representative, increased aid may also change the character of domestic taxation, so that distortionary taxes are on the margin financing not only the public good but also transfers to the favored group. The latter possibility underpins Bauer's (1974) warning that aid would politicize life in developing countries. It also provides some interpretation of the view (Bahl, Kim and Park (1986)) that the cutoff of American aid to Korea in the early 1960s encouraged the emergence of a developmental state there, a view echoed by Williamson (1995) in describing Taiwan's move towards greater export orientation in the 1960s. More generally, the model suggests various ways in which conditionality might be used to increase the effectiveness of aid.

\subsection{Conditional aid}

There are two quite separate roles for conditionality in the aid relationship. The first is to provide the recipient with a way of committing credibly to a course of action that is in the recipient's own interest, independently of the aid inflow. We have assumed thus far in this section that the government can commit to its tax and transfer policy in advance. If it cannot, our earlier discussion of time consistency is relevant and even a fully representative government may find itself on the "wrong" side of the Laffer curve, in a low-investment, high tax equilibrium. ${ }^{29}$ If penalties can be made adequate and credible, conditional aid can then move the recipient to the good side of the Laffer curve. Credibility problems therefore greatly increase the apparent scope for conditionality. Collier (1991) sees aid donors as having taken on precisely this role in post-independence Africa, but with limited success given their own credibility problems. We return to this issue in Section 6.1 below.

The second, more conventional role of conditionality, which we will investigate in this section, is to support aid flows in the face of a conflict of interest between the donor(s) and the recipient. To root this conflict in the recipient country's political economy, we assume that the donor is concerned about the general welfare in the recipient country rather than the welfare of

\footnotetext{
29 As noted by Olson and McGuire (1996), even a highly non-representative government will want to commit to tax and transfer policy in advance, in order to guarantee that the private sector invests in the taxable asset. Making aid flows conditional on non-extortionary policy is one way to do this.
} 
the favored group. This specification is consistent with pure altruism on the part of the donor, but it may also be consistent with other donor motivations. ${ }^{30} \mathrm{~A}$ simple specification that captures this feature is

$$
W=\int\left[u\left(C_{h}\right)+\beta c_{h}\right] d h+\delta X,
$$

where the integral goes over all households (distributed uniformly over $[0,1]$ ) in the recipient country, $X$ is the donor's domestic spending, and $\delta$ is the relative weight the donor attaches to this spending. We have assumed in (5) that household utility is linear in second-period consumption; this is less general than our earlier treatment but simplifies the analysis considerably. ${ }^{31}$ To avoid a corner solution in which all donor resources go to foreign aid, we require that donor altruism be limited in the sense that $\delta>\beta$.

Although the donor's preferences are defined over $C, c$ and $X$, we can readily express them in terms of the fiscal policy variables $t$ and $T$. To do this, note first that the donor faces a domestic budget constraint of the form $X+A=D$, where $D$ is (exogenous) domestic revenue. Combining this with the recipient's budget constraint (3.1) and eliminating $A$, we get the overall constraint

$$
D+t g\left(K_{H}^{*}(t)\right)=X+G+T .
$$

Equation (6) simply states that the total domestic spending of both players is limited by the sum of their tax revenues. This constraint ties $t, T$ and $X$ together, since all other variables are exogenous. Consider a rise in $T$, for example, holding $t$ constant. By (6), $X$ must fall because with $t$ fixed, the rise in transfers must have been financed by an aid inflow. Viewed as a bargaining game, the aid relationship is about determining both the size of the overall revenue pie and its division between alternative uses.

With linear second-period utility, the donor's objective function (5) is of the form $V(t, 0)$ $+\beta T+\delta X{ }^{32}$ Substituting (6) into this objective function, we obtain the donor's valuation of alternative choices of $t$ and $T$ :

$$
W(t, T)=V(t, 0)-(\delta-\beta) T+\delta\left[D+\operatorname{tg}\left(K_{H}^{*}(t)\right)-G\right] .
$$

Equation (7) has two notable features. First, aid flows that generate consumption transfers reduce the utility of the donor. This is a straightforward implication of $\delta>\beta$, and it has a

\footnotetext{
${ }^{30}$ For example, there may be positive cross-country externalities to the general welfare, such as a reduction in spillovers from civil disorder.

${ }^{31}$ With linear second-period utility, the future income distribution is irrelevant from the perspective of the donor, and the donor's preferences can be written as a simple function of $t$ and $T$.

32. With linear second-period utility, $f V(t, T / z)+(1-f) V(t, 0)+\delta X=V(t, 0)+\beta T+\delta X$.
} 
powerful implication for unconditional aid:

Proposition 4: Aid collapse.

A government with $f<f^{c}(G)$ receives no unconditional aid.

Proof: Unconditional aid can be thought of as a Stackelberg game in which the donor moves first, pledging an amount of future aid. The recipient then formulates tax and transfer policy and implements these when the aid flow arrives in period 2. By Proposition 3, a recipient with $f<f^{c}(G)$ will spend any aid inflow on transfers. By (7), this will reduce the donor's welfare. Anticipating this, the donor will choose $A=$ 0 .

The second observation about (7) is that the tax rate can be either too high or too low from the donor's perspective. Holding $T$ constant and starting at $t=0$, a small increase in the distortionary tax increases the donor's domestic spending by more than enough to offset the reduction in investment quality and utility. But as $t$ rises, the deterioration in the recipient's economic performance eventually dominates and donor utility falls.

In Figure A4 we use these observations to replace the Laffer curve in our earlier diagrams with a set of donor indifference curves. Lower indifference curves mean higher utility for the donor, while the reverse is true for the recipient. The donor's indifference curves, like those of the recipient, are vertically parallel. We can show that their turning point takes place where the elasticity of $g\left(K_{H}\right)$ with respect to the tax rate (defined earlier as $\eta(t)$ ), is equal to $1-(\beta / \delta)$. Since $\eta$ is an increasing function of $t$, this takes place to the left of the revenue-maximizing tax rate, denoted $t_{\max }$ in the diagram. We also identify the tax rate $t_{T}(f)$ in the diagram, which is the rate corresponding to tangencies between the Laffer curve and the recipient government's indifference curves. These tangencies take place where $\eta(t)=1-f$. We have drawn the case in which $f<\beta / \delta$, which implies that the donor's indifference curves peak to the left of $t_{T}(f)$.

We can now illustrate the role of conditionality when unconditional aid is undermined by political economy considerations. We begin by arguing that there will typically be gains from aid, even when unconditional aid is zero. This is illustrated in Figure A4, where we assume that $f$ is low enough (given $G$ ) that transfers are positive even in the absence of aid inflows $f$ $<f(G)$ ). The no-aid equilibrium is at point 1 . By Proposition 4, this is also the aid equilibrium in the absence of conditionality, since the recipient's response to aid (indicated by the vertical arrows) makes the donor worse off. The diagram makes clear, however, that although aid is zero without conditionality, the potential gains from aid are strictly positive. Any point inside the hatched area increases the utility of both the donor and the recipient government, relative to the zero-aid point. Proposition 5 generalizes this observation. 
Figure A4

The aid relationship with $f<f^{c}(G)$

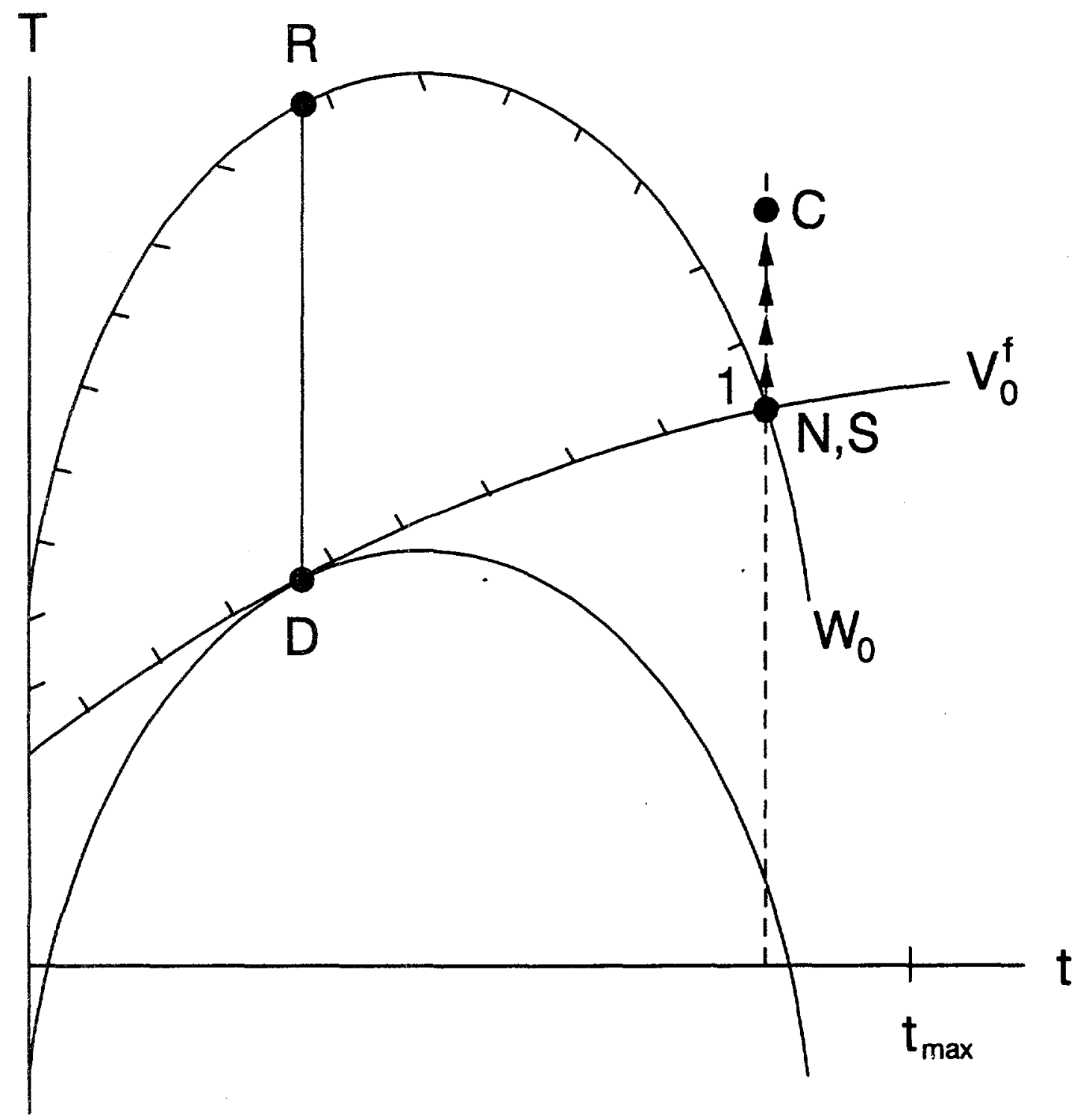

N: no-aid point

$\mathrm{C}$ : unconditional aid

S: "Stackelberg" equilibrium without conditionality

RD: contract curve

: area of gains from aid 
Proposition 5: The gains from aid.

Regardless of the recipient's political economy, there are some values of $G$ for which gains from aid exist. For $f<\beta / \delta$, gains exist for all values of $G$. For $f \geq \beta / \delta$, gains exist whenever $G$ is low enough to induce transfers in the absence of aid or high enough to push the tax rate above the rate satisfying $\eta(t)=1-(\beta / \delta)$.

What is the precise role of conditionality in securing the gains from aid? In the case illustrated in Figure A4, aid-supported conditionality that lowers the tax rate even slightly makes both donor and recipient better off. But a Pareto efficient aid contract would call for a reduction all the way to $t^{c c}$, in order to reach the contract curve. Proposition 6 gives a more complete account of the role of conditionality, distinguishing its role in preventing a collapse of aid from its role in securing an efficient aid contract.

Proposition 6: The role of conditionality.

The role of conditionality depends on the values of $f$ and $G$. Define $G^{c}(f)$ as the critical value of public spending below which transfers are initiated $\left[G^{c}(f)\right.$ solves $\left.f=f^{c}(G-0)\right]$. There are five regions:

(Region 1) For $f<\beta / \delta$ and $G \geq G^{c}(f)$, conditionality is not required to secure some gains from aid, but it is required to secure a Pareto efficient aid contract.

(Region 2) For $f<\beta / \delta$ and $G<G^{c}(f)$, conditionality is required to secure any gain whatsoever from aid.

(Region 3) For $f \geq \beta / \delta$ and $G \geq G^{c}(\beta / \delta)$, a Pareto efficient aid contract can be reached without conditionality.

(Region 4) For $f \geq \beta / \delta$ and $G(f) \leq G<G^{c}(\beta / \delta)$, conditionality has no role; there are no gains from aid.

(Region 5) For $f \geq \beta / \delta$ and $G<G^{c}(f)$, conditionality is required to secure any gain whatsoever from aid.

The five regimes are illustrated in Figure A5.

We conclude this section by discussing the form of conditionality. In Figure A4, the hatched region represents the set of choices of $t$ and $T$ that generate Pareto improvements over the no-aid point. We can think of the players as bargaining over $t$ and $A$, since with $G$ 


\section{Figure A5 \\ Gains from aid and the role of conditionality}

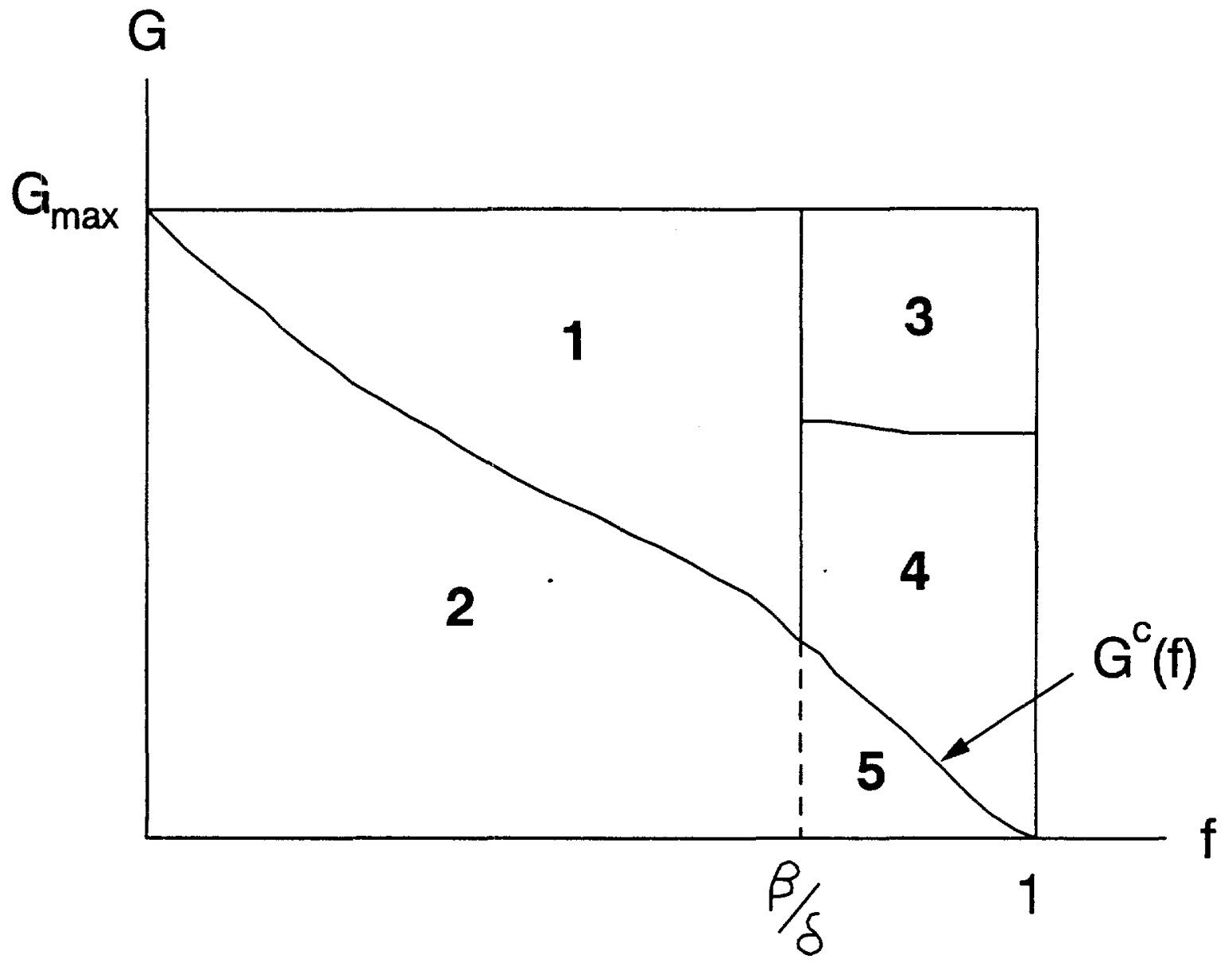

1: Aid positive but inefficient without conditionality.

2: $A=0$ without conditionality; conditionality reduces $t$, and $T$ may rise or fall.

3: Conditionality not needed for efficiency.

4: No gains exist.

5: $A=0$ without conditionality; conditionality reduces both $t$ and $T$. 
predetermined any two of the variables $t, T$ and $A$ determines the third. What combination will be chosen, if both donor and recipient can costlessly enforce commitments regarding aid flows and tax rates? We cannot determine the exact form of a conditional aid contract without specifying the precise bargaining game between the donor and the recipient. We can, however, make the following observations:

\section{Proposition 7: The nature of conditionality.}

Any conditional aid contract reduces the distortionary tax rate. If the donor has substantial bargaining power relative to the recipient, the accompanying fall in tax revenue will be partly financed by an increase in aid and partly by a reduction in transfers. If the recipient has substantial relative bargaining power, the implied reduction in tax revenue may actually be more than offset by aid inflows, allowing a net increase in transfers.

Propositions 4-7 conform with certain features of the evolution of the aid relationship in Africa, notwithstanding the clear weakness of the model in characterizing donor motivations during the Cold War era. The analysis ties the emergence of conditionality in the 1970s to deteriorating domestic policy choices associated with increasingly non-representative political structures. The increasing tightness of conditionality starting in the 1980s, and especially in the 1990 s, can be associated with exogenous events that dramatically increased the relative bargaining power of donors. In the next two sections we discuss various extensions and implications of the analysis.

\section{Extending the analysis}

In the model of Section 4, leaders sacrifice growth for the sake of transfers to a favored group. An alliance between donors and the 'general interest' in recipient countries then creates a strong case for conditionality over tax and tax-like distortions. How robust is this message to extensions or modifications of the model? What challenges does the analysis pose for the design of conditionality? We address the first of these questions in this section, focusing particularly on the nature of personal rule and the sources and implications of policy uncertainty. Section 6 then takes up the implications for conditionality.

\subsection{Autocrats and growth}

Olson (1994) argues that in a system of personal rule the seriousness of the predation problem depends on the planning horizon of the leader. Leaders with long horizons internalize the collective interest in economic growth; those with short horizons sacrifice the collective interest to maximize their short-term rents. A number of African leaders have enjoyed long periods in power; does this invalidate the analysis?

While short horizons exacerbate the underlying conflict of interest (most dramatically in 
the case of time consistency problems), the conflict itself is rooted in the political economy and persists even if leaders have infinite horizons. ${ }^{33}$ Moreover, even with the notional protection of single-party political structures and other constraints on domestic contestibility, executive transitions in Africa have been violent and, in some countries, frequent as well (Sandbrook (1986), Alesina and Perotti (1994)). A high ex ante probability of transition reduces the effective planning horizon, particularly when transitions force incumbents into a position of economic exile (or death) rather than returning them to a normal civilian life. ${ }^{34}$

A final reason why long horizons may fail to rescue development-oriented behavior in systems of personal rule is that leaders face a tradeoff between their own tenure in office and the overall performance of the economy. Very poor performance is to be avoided, since it increases the probability of a coup; but very successful performance may reduce collective action problems in the private sector, create countervailing centers of economic power, and speed institutional innovations that in the absence of external security threats would eventually repudiate or eviscerate personal rule. Thus Diamond, et al (1990) observe that:

"...the most common and in the long run the most important effect of rapid socioeconomic development under authoritarian rule has been to generate pressures and create social structural conditions more conducive to democracy..."[page 19].

A similar tension emerges if causality goes from institutional developments to growth, rather than the reverse. Collier (1991), for example, argues that agencies of restraint like a free press and an independent central bank (or, in principle, conditional aid) contribute to growth by placing limits on predation. But conflicts over current policy choices imply conflicts over the rules governing those choices. Non-representative leaders may therefore actively oppose the development of such agencies, even if they are in the public interest.

These observations strengthen the tension between autocratic rule and growth that is central to the analysis in Section 4. They also bring out an important distinction between external and internal threats in such systems. We noted in Section 4 that a greater externally-driven revenue imperative can transform the policy choices of a non-representative leader into those of a "developmental state". Here the common interest in secure borders overcomes a distributional conflict of interest that would otherwise undercut growth. A similar effect operates with respect to time consistency problems: dissembling is costly even to a non-representative government. But the opposite seems likely to hold if the primary threats are to the tenure or

${ }^{33}$ Boone (1996) studies precisely this case.

34 "Short horizon" effects abound in the African policy literature. In Ghana, insecurity of tenure may help explain the persistence of an overvalued exchange rate (Ansu (1996)). In Kenya, the difference between Presidents Moi and Kenyatta is often attributed to the greater security of the Kikuyu-based Kenyatta regime (Bigsten and Moene (1996)). In Tanzania, the emergence of high-level corruption in the early 1990s may in part be associated in part with the temptations of a second and final term of President Mwinyi, who was constitutionally prevented from running for a third term. 
autonomy of incumbent leaders. These drive a wedge between the general interest and that of the incumbent group, which now acquires an interest in opposing developments that would undercut its own flexibility and longevity. On the empirical side, these distinctions call to mind the contrasting economic performance of authoritarian regimes in Asia, on the one hand, and Africa and Latin America, on the other. Alesina and Perotti (1994) attribute the lack of a systematic cross-country relationship between democracy and growth to the high cross-country variance of outcomes for authoritarian regimes, with high-growth autocracies in Asia balanced by low-growth autocracies in Africa and Latin America.

Conditionality may differ radically if institutional developments are the fundamental issue, and we return to this theme below. We turn first to a discussion of uncertainty, however, emphasizing uncertain succession and reversible reform as two sources of uncertainty in the African environment.

\subsection{Incorporating uncertainty}

We argued above that uncertain succession shortens the planning horizon of incumbent leaders. A second effect, however, is to make the policy regime stochastic. In our model, uncertain succession would mean uncertainty about the composition and potentially the size of the favored group. Future transfer incomes would therefore become stochastic, and if the sizes of contesting groups differed, tax rates would be stochastic as well.

These effects could well strengthen the case for conditionality over the tax rate, to offset the growth-reducing consequences identified in Section 3. A low and effective ceiling on the tax rate, for example, would reduce not only the average distortion (as in Section 4) but also the uncertainty around this average and the uncertainty about future transfer income.

Moreover, conditionality designed to reduce the intertemporal variance of allowable tax rates could improve performance even if average tax rates were unchanged. This is an important area for future work; at the moment the results seem likely to be complex and highly model-dependent. ${ }^{35}$

Policy reform has been a second source of policy uncertainty in Africa, and one that has operated at least as fundamentally within political regimes as across regime transitions. The structural adjustment programs of the 1980 s and their more recent successors have in some cases been associated with an increase in uncertainty and a continued flight to liquidity on the part of the private sector (e.g., Aryeetey (1994)). In part this is because adjustment programs share the characteristics that lead to the waiting behavior characterized by Dixit and Pindyck.

\footnotetext{
35 We emphasized earlier that formalizing these effects is more treacherous in the case of tax uncertainty than in the case of non-stochastic distortions. For example, suppose that two main groups alternate stochastically in power, so that the tax rate follows a two-state Markov process. Aizenman and Marion (1993) imbed such a tax process in an overlapping generations model with irreversible investments. One natural way of characterizing a rise in uncertainty is to ask what happens when the higher of the tax rates increases and the lower of the two decreases. From the low-tax regime, such an increase in uncertainty reduces investment, as one might expect with irreversible investment. But in the high-tax world, investment may increase, in large part because the prospect of a subsequent rechuction exerts a greater attraction.
} 
The programs are inherently complex -- not to mention imperfectly understood even amongst professional economists -- and since the desired reallocation of resources is at least partly irreversible, the domestic private sector has an incentive to await the arrival of new information on the the profitability of investments (as in Rodrik (1989)). An important proximate source of the relevant uncertainty may be the waiting behavior of governments themselves, who implement cosmetic reforms while retaining the option of substantial and irreversible changes. In the case of the private sector the reform environment raises the value of maintaining a liquid portfolio of assets.

By "rationalizing" distortionary policy choices, the analysis of Section 4 suggests a link between policy uncertainty and what political scientists call the "orthodox paradox" of economic reform in Africa: what incentives do incumbent regimes have to reverse economic policies that they themselves had implemented and had not chosen voluntarily to change ${ }^{36}$ Can external pressures cement market-oriented reforms? Concerns about the extent of the orthodox paradox are widespread (see Gordon, 1993 for example). Leith and Lofchie (1993) analyze the Ghanaian case:

"The principal explanation .. [for why "the reform program is not generating substantial ongoing economic growth" is that] .. the [Rawlings] government remains ambivalent in its underlying attitude towards the idea of a market-based economy and this ambivalence continues to engender a certain amount of insecurity and reluctance among would-be Ghanaian entrepreneurs" (p. 280).

The government's ambivalence reflects the tension discussed earlier between the gains accruing from reforms which solve the government's commitment problems and the costs of increased contestability on the other. The major policy reforms of the 1990s, more so than the reforms of the 1980s, have as a common feature the substantial removal of discretion in tax and tax-like policies. Thus policies of exchange rate unification, trade liberalization, financial liberalization, privatization and in particular the support for competitive elections, all undermine the scope for executive discretion, improving the capacity to commit to policy measures, but at the cost of making the political system more contestable. The immediate result may be partial, fitful implementation ${ }^{37}$ and an increase in the uncertainty faced by the private sector.

\footnotetext{
${ }^{36}$ More generally, the orthodox paradox is the claim that market-oriented reforms, the aim of which is to diminish the role of government in favor of private markets, require a strong and committed state to be successful. Reforms can fail, in this view, because they are at odds with the executive's preferences (as in our discussion); or because they violate a political equilibrium in other ways, for example by removing patronage mechanisms essential to bureaucratic compliance and/or political stability.

${ }^{37}$ Bates and other suggest that the partial implementation of programs of reform reflects the fact that incumbent rulers will only seek to implement reforms up to the point that the marginal gain (additional resources) equal the marginal cost (constraints on autonomy).
} 


\section{Implications for conditional aid}

The discussion of the previous section complicates but does not undermine the rationale for policy conditionality identified in Section 4 . In this section we bring donors back into the picture and explore some of the limitations of conditional aid.

\subsection{The Samaritan's Dilemma}

In the previous section, the donor's distaste for direct transfers allowed it to credibly threaten a withdrawal of aid if conditions were not met. In reality, donors may find it difficult to carry through such threats. Policy failures that weigh heavily on the disenfranchised will confront donors with strong pressures to renegotiate, in the hope of channeling some portion of aid flows to these groups in period 2. Donors in this situation face a "Samaritan's Dilemma" (Buchanan (1975)): unable to resist protecting the private sector when policy failure occurs, they will fail to protect the private sector from policy failure itself. In response the private sector, believing (correctly) that the donor is unable to act as its agent in restraining the predatory instincts of the government, will be unprepared to commit resources to investments with high social but low (after-tax) private returns. In an extreme case, a non-representative government may be able to capture the donor in a permanent aid relationship that replicates the outcome of unconditional aid discussed in section 4 . In this case, even a permanent flow of aid is rendered ineffective by the donor's inability to commit to punish the recipient.

The time inconsistency of donor threats will often be less starkly defined. For example, suppose that the donor has the capacity to provide poverty relief directly to the private sector (through direct delivery, for example, or through the use of NGOs or other means of bypassing central government). If there are costs involved with working through the government (arising from the "institution-building" aspect of conditional lending), then from an ex post perspective, poverty alleviation through the government is less effective, dollar-for-dollar, than direct service delivery. If the optimal policy ex ante is to incur the institution-building costs, the donor faces a time consistency problem. In the absence of a pre-commitment mechanism, it will choose direct delivery ex post.

The severity of the Samaritan's Dilemma may vary across types of donor. Multilateral donors such as the Bretton Woods institutions are not constitutionally required to lend to all member governments, but their internal governance structures may make selectivity difficult or undercut its credibility (Collier, Guillaumont, Guillaumont and Gunning (1997)). In this respect, bilateral donors may find it easier to threaten an individual country with the withdrawal of aid. However, bilateral donors whose own private sectors have developed coalition interests with the recipient government may be much less unconstrained than this contrast suggests. For example, ex-colonial donors such as the UK and France may be equally unable to credibly threaten to cut off aid. Clientilist interests may also arise from more self-interested donor concerns, such as avoiding the immigration consequences or regional or 
humanitarian spillovers of economic hardship in the recipient country. ${ }^{38}$

Samaritan's Dilemma problems of this sort have given rise to an extensive literature on the design of schemes for resource transfers aimed at bolstering the donors capacity to induce changes in recipient behavior (see for example, Bruce and Waldeman, (1988) and Coate (1995) on altruism and the Samaritan's dilemma in welfare transfers, and Pietrobelli and Scarpa (1992) and Svensson (1995) on altruism and donor credibility).

\subsection{Dependence and graduation}

A deeper limitation of policy conditionality emerges when we view donor and recipient as interacting through time, not simply in a one-shot relationship. On the positive side, repeated interactions may generate some limited scope for mechanisms that alleviate time-consistency problems. But even if time consistency problems are solved, a fundamental limitation remains: conditionality over $t$ alone locks the donor and recipient into a permanent relationship. Unless either $f$ or $G$ changes over time, either autonomously or in interaction with economic growth or aid flows, the donor must act as an agency of restraint in perpetuity. This is inconsistent with the preferences of donors and the private sector, both of whom regard "graduation" from aid dependency as a longer-run objective of aid policy.

While an explicit analysis of graduation is beyond the scope of this paper, the analysis of section 4 provides some clues for thinking about the basic issues. In particular, the distinction between $t$ and $f$ in that model mirrors an important practical distinction between what might be called "policy" and "process" conditionality, one that becomes essential when repeated interaction is considered.

Donors in section 4 (and in the 1980s in Africa) treat political economy (as summarized by $f$ ) as predetermined and use conditionality to restrict the government's choices of economic policy ( $t$ and $T$ ). Aid bargains are conditional in precisely those cases in which the contract curve is off the expansion path for the $f$-type government (e.g., the path from $\mathrm{N}$ to $\mathrm{C}$ in Figure A3). However, noting that the underlying budget constraint is independent of the political economy, each point on the contract curve is also located on an expansion path for some other value of $f^{*}>f$. In principle, therefore, it would be possible to arrive at the same $(T, t, A)$ outcome by defining the aid contract in the current period in the form $\left[f^{*}, A\right]$. In this case aid is conditioned directly on a change in the recipient's political economy, and the political economy itself then (unconditionally) determines the level of taxation and transfers associated with the aid flow. ${ }^{39}$ Rather than being defined over policy choices, conditionality in this case is

\footnotetext{
${ }^{38}$ As emphasized in the introduction, the end of the Cold War has removed an important global-strategic motivation for aid clientilism in Africa. Concerns about the spread of militant Islamic influences in Africa may begin to emerge in a similar role, at least for the US.

${ }^{39}$ Notice also that exogenous changes which altered $G$ could also serve to alter the character of a given political econorny, where as a result of the collapse of an external security threat the reduced (distortionary) cost of providing $G$ induces the same government to start making transfers.
} 
defined over the policy process itself. This type of conditionality is clearly much less precise, but has tended to consist of, for example, reforms to constitutional and legislative structures through competitive parliamentary elections and the shifting of power to legislative committees; judicial reforms; support for key institutions in the realm of civil society, such as trade unions and a free press; and policies supporting the emergence of restraining interest groups in the private sector, such as privatization programs aimed at widening share ownership.

In a one-shot aid relationship, the two forms of contract seem equivalent. What differentiates them in a multi-period context is the possibility that $f$ is a "deeper" parameter than $t$ or $T$, one that is less easily reversed. ${ }^{40}$ Unlike changes in $t$, which are temporary, changes in $f$ alter the recipient's no-aid position, $N$, in future periods. An increase in $f$ shifts the government to a new position of tangency on the no-aid laffer curve, shifting the no-aid point in Figure A3 some distance to the left of $N$, consistent with a lower value of $t$ and lower (or zero) $T$. The no-aid point in these circumstances is no longer the "threat point" as in the case of the aid contract defined over current policy choices, but the desired outcome of conditionality over the policy process.

If changes in $f$ are irreversible, the recipient will require greater compensation to accept a change in $f$ than to commit to the resulting $t$ for a single period. To the favored group, the cost of accepting conditionality over $f$ is the present value of the future stream of rents foregone. Unless the recipient fully discounts the future beyond the next period, political conditionality will be more costly, particularly if there is scope for rents to accrue from the time inconsistency of the donor. The aid flow required to change the policy process will therefore be higher than that required simply to alter the recipient's policy choice in a one-shot bargain. Two features of the 1990s, however, make the observed shift of donors towards "political conditionality" less surprising. First, the greater unanimity and stronger relative bargaining power of donors has enhanced their credibility, undercutting the expected future rents of recipients in the aid relationship. Second, internal pressures for democratization have increased the discount rate of government leaders by reducing their expected length of tenure.

The possibility of altering $f$ irreversibly therefore brings out possibilities of graduation which previously were not available. Of course, if the donor is not credible then whether conditionality attaches to the political economy or to the tax rate and level of transfers is immaterial. However the relevant difference between the two approaches is that $f$-conditionality requires donor credibility only over the short-run, not permanently. In sufficiently straitened circumstances incumbents may discount the future heavily and accept conditionality over $f$ even though it may undermine their discretionary powers in the future.

\footnotetext{
${ }^{40}$ The recent literature on political lobbying examines the issue of policy persistency from the perspective of behavior of groups of net beneficiaries for whom it becomes worthwhile to resist return from the policy (see Coate and Morris (1995)). Other important factors in the creation of persistence effects are that there may be uncertainty over the consequences of reforms so that only once reforms are introduced will groups fight to retain newly acquired entitlements. Similarly, coordination failures or threshold effects may prevent the emergence of agencies of restraint, but once established -- perhaps through conditional aid -- they will not be reversed.
} 


\subsection{Configuring process conditionality}

The superficial attraction of conditionality on $f$ masks at least two fundamental problems. The first, noted above, is understanding how and why changes in $f$ may be more permanent than changes in $t$. The second is understanding not only how the institutions that are summarized by the parameter $f$ constrain the actions of the government, but more importantly how they evolve over time and how their evolution is influenced by aid. The following observations illustrate the scope of these problems.

First, it may be that societies eventually solve their development problems as a result of the evolution of $f$ over time. This may result from exogenous factors acting as stimuli to changes in $f$, or through the endogenous determination of $f$ itself. The latter process is described in Persson and Tabellini (1994) and in North and Weingast (1989) where $f$ (in our parlance) is no longer parametric but is a function of the level and distribution of productive capital. As the stock of capital grows and particularly as its distribution becomes more concentrated (which may be faster or slower depending on the initial size of $f$ ), so the incentive to constrain the predatory instincts of the government increases, and the political economy is able to sustain low taxation. ${ }^{41}$

It is tempting to take these examples as indicating a specific role for aid, either conditioned over current policy choices or over the political economy itself. For example, taking the Persson and Tabelinni case (temporary) aid conditioned over $T$ and $t$, which accelerates the accumulation of $K_{H}$, would eventually lead to the emergence of a self-sustaining political economy in which there is a sufficient economic stake in the taxable assets to ensure that the taxation instincts of the government are circumscribed. In these circumstances, direct conditionality on $f$ may not be necessary to bring about graduation: simply holding the recipient's feet to the fire long enough will suffice. Coate and Morris (1995) apply this logic in a lobbying model of political equilibrium, and show that there are conditions under which policy choices underpinned by temporary conditionality can become irreversible. Similarly, direct conditionality over $f$ may be required to generate graduation when collective action failures prevent the independent emergence of institutions and the growth of $f$. In this case, aid conditioned directly on the political economy may help to internalize the externalities, mirroring the role that early views of foreign aid expected external financial capital to play in solving big-push externalities. Specifically conditionality which reduces information costs -for example through conditionality on freedom of speech and association or on legal representation -- may contribute to the increase in $f$.

Set against these examples, however, is the possibility that aid may serve to crowd out the development of domestic agencies of restraint. This, of course, returns to the critique of aid which motivated this paper. One such example would be where aid undercuts the emergence of social contracts that support ex-ante policy announcements. For example, in the social contract

\footnotetext{
41 Persson and Tabellinni (1994) focus on the capacity of different forms of political organization to constrain governments, arguing that "representative" forms of democracy in which legislative power is delegated to those most heavily endowed with taxable assets will secure low taxation more easily than "direct" forms of democracy.
} 
model of Soskice, Bates and Epstein (1992) ${ }^{42}$, a rule-based institution solves the time-consistency problem of incumbent government. Political deputies (the young generation), knowing that they will inherit the instruments of office in the future, have an incentive to abide by a social contract in which they incur the costs of monitoring the current incumbent government. By shouldering the costs of monitoring today they raise the current level of investment, which raises the future tax base and thus their own potential revenue ${ }^{43}$ However, this form of contract relies on two important factors. The first is that politicians must have political ambition, in the sense defined above. Their interest in power must exceed the capitalized value of the rents that may accrue from expropriation. The second crucial factor is that the incumbent must be accountable to the requirements of the young generation: "leaders must not be able to replace deputies who refuse to cooperate with leaders who abuse their positions" (Soskice et al p. 554). In these circumstances aid which allows incumbents to resist the discipline of their deputies, or aid which serves to blunt the political ambition of the deputies will lead to a collapse of the institution of restraint and a reversal to a low-investment, low-growth situation.

In all three of these cases we are faced with a much greater problem, namely knowing how, in practice, aid flows would interact with nascent political institutions. As it is, the positive theory of institutional evolution is in its infancy: at this stage this paper can only highlight what seem to be the important component mechanisms. However we do know that poorly designed or inadequately implemented or enforced conditionality over $f$ may itself be an important source of uncertainty. Rodrik (1989) used this observation to argue that sustainable but modest economic policy reforms may be superior to those that would generate higher welfare if sustained, but that have a substantial probability of reversal. A similar argument holds with respect to conditionality over $f$. Conditionality with respect to modest but sustainable institutional changes may well be superior to more ambitious conditions that generate larger uncertainties.

\section{Conclusions}

To say that institutional failures are central to Africa's poor economic performance is not to repudiate earlier interpretations based on policy failures and capital shortages. In the framework developed here, institutional failures produce policy failures which in turn produce capital shortages or the equivalent. The problem, instead, is that the design of effective aid programs depends on the diagnosis. Our aim in this paper has been to capture the analytical

42 This is broadly the same as the Kotlikoff, Persson and Svensson (1988) model.

${ }^{43}$ In this overlapping-generations model the intergenerational social contract emerges as a sub-game perfect equilibrium solution to the time-consistency problem under the condition that the monitoring generation has a sufficient interest in its own future status. Given this political "ambition", which means that deputies value the future more highly than does the market, deputies not only incur the cost of monitoring incumbents today, but also expect to be constrained to the same extent in the future by their successor generation. 
core of the evolving (primarily external) diagnosis of the African development problem. In attempting this we have tried to be guided by the broad stylized facts about the African policy environment and by the main features that political scientists associate with the African state. Three basic observations make this a relevant, and unfinished exercise. First, donors as a group are currently in a position of overwhelming bargaining strength with respect to major African aid recipients, with extraordinary scope for implementing the political and institutional conditionality suggested by the current diagnosis. Second, while the political economy and institutional development literatures are full of potentially relevant material, they offer little systematic guidance as to what constitutes best practice for donors when institutional failures are important. Third, the decade of the 1990s has seen the most substantial political developments in many African countries since independence. These changes open new opportunities for donors but at the same time place a premium on understanding the underlying continuities that will condition the sustainability of alternative interventions.

We conclude in this section with a list of our main points and suggestions for further work:

- Tax and tax-like distortions tend to be high and volatile in Africa. These influence the allocation of national wealth and are capable, according to standard economic theory, of reducing both the level and the productivity of domestic investment. While more empirical evidence is required, the composition of domestic investment appears to be more important in explaining poor African growth than the level of domestic investment.

-- Policy-generated uncertainty plays an important but underemphasized role in the literature on African political economy. Such uncertainty can activate socially inefficient self-insurance mechanisms that lower growth. When leaders have substantial discretion over policy, as in most African countries, executive transitions can be a major source of policy uncertainty.

- Political scientists emphasize the heavy use of patronage in African systems of personal rule. Many of the unifying themes of this literature are well captured by a simple analytical model in which governments use distortionary taxes to finance transfers to politically powerful groups.

- A government that is captive to a favored group will trade off growth for transfers, provided the favored group is sufficiently small relative to the government's disposable resources. In such a case, conditional aid can be completely ineffective in spurring investment and growth even when the potential gains from aid are large.

- Conditionality is required to secure the gains from aid when non-representative political structures generate a conflict of interest between donors and recipient governments. When donors are in a strong bargaining position, conditionality agreements that mandate a reduction in distortionary taxation will also require that some portion of lost 
revenues be made up by cuts in politically-motivated transfers. Policy conditionality is difficult to enforce, however, and even when perfectly enforceable is subject to the problem of aid dependency.

-- To avoid aid dependency, donors must focus on conditionality that shifts the "no-aid" point. This provides an interpretation of current donor efforts in the area of democratization and institutional development. The shift from policy to "institutional" conditionality reflects an attempt by Africa's donors to re-cast the aid relationship from one that at best secures temporary policy changes in perpetuity to one that permanently alters institutions in favor of sustained growth and development.

The last observation brings us back to the issues that motivated this paper. In the end, a diagnosis that attributes aid ineffectiveness and low growth to institutional failures raises more questions about the appropriate design of aid conditionality than it answers. Analytical models that treat the political economy as given (as by $f$ and $G$ in our case) should prove useful in exploring the diagnosis and posing the relevant questions; but a more complete understanding of aid effectiveness requires that the political economy be endogenized. This is an extremely important area for empirical and analytical research. 


\section{Appendix 1: Self-insurance, growth and taxation}

In this Appendix we use a stylized model to show that the self-insurance mechanisms studied at the microeconomic level by Paxson (1990), Morduch (1994,1995), and others can affect the aggregate growth rate. The model is extremely simple; it combines a resource-allocation decision by risk-averse firms with an economy-wide intertemporal spillover mechanism. There is no claim to generality here; the aim is instead to suggest that the mechanisms at work are potentially important enough to warrant further study.

Private income risk and aggregate growth

We use an overlapping-generations model in which risk-averse producers (e.g., peasant households) live for two periods. In the first period of life, household $j$ divides its labor time between a safe, low-yielding project (or crop) and a risky, high-yielding project. All income arrives in the second period and is consumed then; there is no consumption in the first period. The average product of labor is $A>0$ for the safe crop and $A\left(1+x_{j}\right)$ for the risky crop, where $x$ is a random variable with that has positive expected value but can be negative with strictly positive probability. These restrictions guarantee that the household will typically find an interior solution in which it spends some time on each crop.

Defining $a$ as the fraction of labor time allocated to the risky project, the household's second-period income is given by $y_{j}=\left(1+a x_{j}\right) A$. With a unit of labor time to allocate, the household solves the problem

$$
\left.\operatorname{Max} E U\left(y_{j t}\right)=E U\left[1+a x_{j i}\right) A\right]
$$

where the utility function $U$ is increasing and concave in income. This problem has identical structure to the standard portfolio problem in which the investor maximizes the expected utility of end-of-period wealth (e.g., Ingersoll (1987)). Letting $a^{*}$ be the household's optimal share of labor allocated to the risky project, we have the first-order condition

$$
E\left(U^{\prime} \cdot y_{a}\right)=(1-t) x E\left(U^{\prime} \cdot x\right)=0,
$$

where $y_{a}$ is the partial derivative of $y$ with respect to $a$. Letting $w$ be a parameter that induces a mean-preserving spread on the distribution of $x_{j}$, (A2) can be solved for the optimal supply of labor to the risky project:

$$
a^{*}=a^{*}(A, w) \text {. }
$$


An increase in $w$ makes the risky crop riskier, reducing the fraction of labor allocated to it. A rise in $A$ is the equivalent of an increase in wealth in the standard portfolio problem; it increases (decreases) time allocated to the risky crop provided that relative risk aversion is increasing (decreasing).

We move to the aggregate level by assuming: (i) that the household-level shocks $x_{j}$ are independently and identically distributed; (ii) that productivity spillovers are proportional to lagged output per household; and (iii) that households have constant relative risk aversion. The first of these assumptions implies that uncertainty washes out in the aggregate; the second implies that the "portfolio share" $a$ is independent of core labor productivity $A$. Under these assumptions, aggregate output $Y_{t}$ is the nonstochastic quantity

$$
Y_{t}=[1+a *(w) \mu] A N,
$$

where $\mu=E\left(x_{j}\right)>0$ is the expected value of $x_{j}$ and $N$ is the (large) number of households. In general, of course, shocks to weather or world agricultural prices will induce a correlation between the $x_{j}$ 's across households, making aggregate income a random variable. This would convert our model into a stochastic growth model but would not otherwise change anything of substance. We are assuming that private insurance and credit markets are unavailable even to handle idiosyncratic risk, for reasons (not modeled here) like moral hazard and legal restrictions on the offering of labor as collateral.

To introduce productivity spillovers that are proportional to lagged output per household, we use $A_{t}$ to denote core productivity for households born in period $\mathrm{t}-1$ :

$$
A_{t}=b \frac{Y_{t-1}}{N}, \quad b>0
$$

Combining (A5) and (A4), we can solve for the growth rate of aggregate output, which is given by

$$
g=\left[1+a^{*}(w) \mu\right] b-1 .
$$

The main results are now obvious:

Result 1. A mean-preserving spread in the yield of the high-yielding project lowers the aggregate growth rate.

Proof: By (A2), a rise in $w$ causes risk-averse households to reduce the time allocated to the high-yield project. By (A6), this reduces the growth rate. 
Result 2. The private market generates too little risk-taking.

Proof: Since all risk is idiosyncratic, the social optimum occurs where labor is devoted entirely to the project with higher expected yield: $a=1$. The private market generates too little risk-taking in the absence of mechanisms to insure idiosyncratic risk (we assume an interior solution here).

Taxation and growth with self-insurance

Uncertainty about tax rates, which presumably is at least as uninsurable for domestic residents as uncertainty about pre-tax returns, may affect growth through the self-insurance mechanisms studied above. To make this point obvious assume that $x_{j}=\mu$ in the model above, so that the high-yielding project is safe. In the absence of taxation, the higher-yielding project dominates the lower-yielding one (recall that $1+\mu>1$ ) and households allocate labor only to the high-yielding project. The private market therefore generates the socially optimal allocation. Suppose, however, that the government levies a proportional tax on the high-yielding project (the low-yielding activity can be thought of as a tax shelter), and that the tax rate is stochastic from the perspective of the individual household. The stochastic tax can easily induce the risk-averse household to diversify away from the socially higher-yielding project, with the result of a fall in aggregate growth.

The effect of stochastic tax rates on portfolio allocation was studied by Ekern (1971) and Hazome (1975) but has received very little attention since then. The discussion here suggests that this is an interesting avenue for further work. 


\section{Appendix 2: Proof of Proposition 1}

Define $L=\operatorname{tg}\left(K_{H}^{*}\right)$ as revenue from the distortionary tax. The first-order conditions for problem (3) are then

$$
V_{t}+\lambda L_{t}=0
$$

$$
V_{z}(f)-\lambda+c=0
$$

where $\lambda$ and $c$ are the lagrange multipliers associated with (3.1) and (3.2), and where $L_{t}$ denotes the derivative of $L$ with respect to $t$, which is the slope of the Laffer curve $L_{t}=t g_{t}+$ g). Note that there should also be a constraint requiring $t \geq 0$, but as long as $G>A$, this constraint is never binding.

To verify our earlier graphical analysis, note that equations (4.1) and (4.2) imply

$$
-f\left(V_{t} / V_{2}\right)=L_{t}+c\left(f / V_{2}\right) L_{t}
$$

The left-hand side of (5) is the slope of an indifference curve. If the nonnegativity constraint on transfers is not binding (so that $T$ is positive and $c=0$ ), the right-hand side of (5) is the slope of the Laffer curve and the optimum takes place at a point of tangency, as discussed in the text. It is straightforward to verify that the second-order condition holds for the production function $g\left(K_{H}\right)=K_{H}{ }^{a}, 0<a<1$, for $a \geq 1 / 2$ (the latter condition is sufficient but not necessary).

We now show that $f=1$ implies $c>0$, so that transfers are zero for a fully representative government. By the envelope theorem, $V_{t}=-\beta U_{2} g\left(K_{H}\right)$ and $V_{z}=\beta U_{2}$. Letting $\eta$ be the elasticity of the output function $\left(\eta=-\operatorname{tg}^{\prime}(t) / g(t)>0\right)$, we can use (4.1) and (4.2) to write

$$
\lambda=1 /(1-\eta)=1 / f+c / \beta U_{2} .
$$

The shadow price $\lambda$ is nonnegative, so we know that at an optimum, $0<\eta \leq 1$. It follows that $\lambda>1$. But this in turn implies that if $f=1$, we must have $c>0$.

To show that (3.2) remains binding for "sufficiently" representative governments, simply note that with $T=0$, the tax rate is tied down by the Laffer curve (the optimal $t$ solves $t=$ $(G-A) / g(t))$. But since $\eta$ is a function only of $t$, this ties down the value of $\eta$ and therefore of $\lambda$ in (6). The cutoff value of $f$ is therefore given by (6) with $c=0$ :

$$
f^{c}=(1-\eta)<1 .
$$

This establishes Proposition 1. 


\section{References}

Abel, A.B. and J. C. Eberly (1995), "The Effects of Irreversibility and Uncertainty on Capital Accumulation", NBER Working Paper 5363, November.

Agenor, P.-R. and P. Montiel (1995), Development Macroeconomics. Princeton: Princeton University Press.

Ahmad, E. and N. Stern (1990), "Taxation for Developing Countries", in H. Chenery and T.N. Srinivasan, eds, Handbook of Development Economics. Amsterdam: North-Holland.

Aizenmann, J. and N. Marion (1993), "Policy Uncertainty, Persistence and Growth" ", Review of International Economics 1(2), January: 145-63.

Ake, C. (1993), "Rethinking African Democracy"", in Larry Diamond and Marc F. Plattner, eds, The Global Resurgence of Democracy, Baltimore: The Johns Hopkins University Press: 70-82.

Alesina, A. and R. Perotti (1994), "The Political Economy of Growth: A Critical Survey of the Recent Literature", World Bank Economic Review 8(3), September: 351-71.

Ansu, Y. (1996), "Macroeconomic Aspects of Multiple Exchange Rate Regimes: The Case of Ghana.", in M. Kiguel, J.S. Lizondo and S.A. O'Connell, eds, Parallel Exchange Rates in Developing Countries, London: Macmillan, forthcoming.

Aryeety, E. (1994), "Private Investment Under Uncertainty in Ghana", World Development 22(8): 1211-21.

Atkinson, A. and J. Stiglitz (1980), Lectures in Public Finance, McGraw Hill, New York.

Azam, J.-P. (1995), "How to Pay for the Peace? A Theoretical Framework with Reference to African Countries", Public Choice, Vol 83, pp 173-184.

Bahl, R.W., C.K. Kim and C.J. Park (1986), Public Finances During the Korean Modernization Process. Cambridge, MA: Harvard University Press.

Bates, R.H. (1981), "Toward a Political Economy of Development: A Rational Choice Perspective." California Series on Social Choice and Political Economy, no. 14, Berkeley and London: University of California Press, 1981.

Bates, R.H. (1996), "Institutions as Investments", mimeo, African Economic Research Consortium, Nairobi. 
Bates, R.H. and A.O. Krueger, eds (1993), Political and Economic Interactions in Economic Policy Reform: Evidence from Eight Countries, Oxford: Basil Blackwell.

Bauer, P.T. (1974), "Foreign Aid Forever?", Encounter, March.

Bauer, P.T. and B. Yamey, (1982), "Foreign Aid: What is at Stake?" Public Interest, Summer.

Berry, S. (1993), "Coping with Confusion: African Farmers' Responses to Economic Instability in the 1970s and 1980s", in T. M. Callaghy and J. Ravenhill, eds, Hemmed In: Responses to Africa's Economic Decline, New York: Columbia University Press.

Bhardan, P. (1995), "The Contributions of Endogenous Growth Theory to the Analysis of Development Problems: An Assessment", in J. Behrman and T.N. Srinivasan, eds, Handbook of Development Economics, Volume IIIA. Amsterdam: North-Holland.

Bigsten, A. and K. Moene (1996), "Growth and Rent Dissipation: the Case of Kenya", Journal of African Economies Vol 5 pp 177 - 198.

Boone, Peter (1996), "Politics and the Effectiveness of Foreign Aid", European Economic Review. Vol 40, pp 289-32.9.

Bruce, N. and M. Waldman (1988), "Transfers in Kind: Why They Can Be Efficient and Nonpaternalistic", American Economic Review 78(5), December: 1034-45.

Buchanan, J. M. (1975), "The Samaritan' Dilemma", in Edmund S. Phelps, ed, Altruism, Morality and Economic Theory. New York, Russell Sage Foundation: 71-85.

Callaghy, T. and J. Ravenhill (1993), Hemmed In: Responses to Africa's Economic Decline, New York: Columbia University Press.

Caprio, G. and P. Honohan, eds (1991), Instruments of Monetary Policy in Africa. Washington, DC: The World Bank.

Cashin, P. (1994), "Government Spending, Taxes, and Endogenous Growth", IMF Working Paper No. 94/92, Washington, DC.

Cass, D. (1965), "Optimum Growth in an Aggregative Model of Capital Accumulation", Review of Economic Studies Vol 32, pp 233-240.

Chenery, H. B. (1967), "Foreign Assistance and Economic Development", in J.H. Adler, ed, Capital Movements: Proceedings of a Conference held by the International Economic 
Association, London: Macmillan.

Claessens, S. and D. Naude (1993), "Recent Estimates of Capital Flight", World Bank PRE Discussion Paper No. 1186.

Coate, S. (1995), "Altruism, the Samaritan's Dilemma, and Government Transfer Policy", American Economic Review Vol 85, pp 46-57.

Coate, S. and S. Morris (1996), "Policy Persistence", mimeo, Department of Economics and Wharton School, University of Pennsylvania.

Collier, P. (1991), "Africa's External Economic Relations 1960-1990", African Affairs.

Collier, P. and R. Garg (1996), "On Kin Groups and Employment in Africa", mimeo, Centre for Study of African Economies, Oxford.

Collier, P., P. Guillaumont, S. Guillaumont, and J. W. Gunning (1997), "Redesigning Conditionality", World Development 25(9): 1399-1407.

DeRosa, Dean A. (1992), "Protection and Export Performance in Sub-Saharan Africa", Weltwirtschaftliches Archiv 128: 88-124.

Devarajan, S., V. Swaroop and H. Zou (1995), "The Composition of Public Expenditure and Economic Growth", mimeo, World Bank, July.

Diamond, P. (1965), "National Debt in a Neoclassical Growth Model", American Economic Review, Vol 55, pp 1126-1150.

Diamond, L., J. J. Linz and S.M. Lipset (1990), Politics in Developing Countries: Comparing Experiences with Democracy, Colorado, Lynne Rienner Publishers, Inc.

Dixit, A.K. and R. Pindyck (1993), Investment under Uncertainty, Princeton University Press.

Dollar, D. (1992), "Outward-Oriented Developing Economies Really Do Grow More Rapidly: Evidence from 95 LDCs, 1976-1985", Economic Development and Cultural Change; Vol 40, pp. 523-44.

Domar, E. and R. Musgrave (1944), "Proportional Income Taxation and Risk Taking" Quarterly Journal of Eonomics Vol 58, 388-422.

Easterly, W. (1992), "Endogenous Growth in Developing Countries with Government-Induced Distortions", in V. Corbo, S. Fischer and S. Webb, eds, Adjustment Lending Revisited: 
Policies to Restore Growth. Washington D.C., The World Bank, 1992.

Easterly, W. (1994), "Economic Stagnation, Fixed Factors, and Policy Thresholds", Journal of Monetary Economics 33: 525-57.

Ejkern, S. (1971), "Taxation, Political Risk and Portfolio Selection", Economica Vol 38, pp. 421-30.

Elbadawi, I. and B. Ndulu (1994), "Long-Term Development and Sustainable Growth in Sub-Saharan Africa", mimeo, African Economic Research Consortium, Nairobi, presented at SAREC International Colloquium on New Directions in Development Economics, Stockholm, March 1994.

Elbadawi, I and K. Schmidt-Hebbel (1996), "Macroeconomic Policies, Instability and Growth in the World", mimeo, African Economic Research Consortium, Nairobi, presented at AERC Research Workshop, December 1996.

Fielding, D. (1996), "Aggregate Investment in South Africa:A Model with Implications for Political Reform", mimeo, Department of Economics, University of Nottingham.

Fischer, S. (1993), "The Role of Macroeconomic Factors in Growth", Journal of Monetary Economics, Vol 32, pp. 485-512.

Floyd, R., C.S. Gray, and R.P.Short (1984), Public Enterprises in Mixed Economies: Some Macroeconomic Aspects, Washington, DC: International Monetary Fund.

Friedman, M. (1958), "Foreign Aid," Yale Review 47(4): 500-16.

Gavin, M. and Hausmann, R. (1995), "Determinants of Macroeconomic Volatility in Developing Economies," mimeo, Inter-American Development Bank, February.

Gemmell, N. (1993), "Fiscal Dependence on Trade Taxes and Economic Development: Some New Evidence," Scottish Journal of Political Economy 40(1), February: 56-68.

Giovannini, A. and M. de Melo (1993), "Government Revenue from Financial Repression", American Economic Review, 83(4), September, pp. 953-63.

Gordon, D.F. (1993), "Debt, Conditionality, and Reform: The International Relations of Economic Restructuring in Sub-Saharan Africa", in T. Callaghy and J. Ravenhill Hemmed In: Responses to Africa's Economic Decline, New York: Columbia University Press.

Hazome, Y. (1975), "Taxation, Political Risk and Portfolio Selection: A Critical Note" 
Economic Studies Quarterly, Vol 26, pp 130-32.

Ingersoll, J.E. (1987), Theory of Financial Decision Making, Totow, NJ: Rowman and Littlefield.

Khan, M. S. and N. Ul Haque (1985), "Foreign Borrowing and Capital Flight: A Formal Analysis", DM/85/39, International Monetary Fund, July.

King, R., and R. Levine (1993), "Finance, Entrepreneurship, and Growth: Theory and Evidence", Journal of Monetary Economics, 32(3), December, pp. 513-42.

Kotlikoff, L., T. Persson and L. Svensson (1988), "Social Contracts as Assets: A Possible Soluton to the Time-Conisistency Problem", American Economic Review Vol 78 pp. 662-677.

Knack, S. and P. Keefer (1995), "Institutions and Economic Performance: Cross-Country Tests using Alternative Institutional Measures", Economics and Politics, Vol 7, pp. 207-227.

Leith, J. C. and M. F. Lofchie (1993), "The Political Economy of Structural Adjustment in Ghana", in R.H. Bates and A.O. Krueger, eds (1993), Political and Economic Interactions in Economic Policy Reform: Evidence from Eight Countries, Oxford: Basil Blackwell.

Mauro, P. (1995), "Corruption and Growth", Quarterly Journal of Economics, August, pp. $681-712$

McGuire, M. and M.Olson (1996), "The Economics of Autocracy and Majority Rule", Journal of Economic Literature Vol 34 pp 72-96.

Morduch, J. (1994), "Poverty and Vulnerability", American Economic Review (Papers and Proceedings) 84(2), May: 221-225.

Morduch, J. (1995), "Income Smoothing and Consumption Smoothing", Journal of Economic Perspectives 9(1), Summer: 103-14.

North, D.C. (1990), Institutions, Institutional Change, and Economic Performance, New York: Cambridge University Press.

North, D.C. and B.R. Weingast (1989), "Constitutions and Commitments: The Evolution of Institutions Governing Public Choice in Seventeenth Century England", Journal of Economic History Vol 69, pp. 803-32.

Nurkse W. (1953), Problems of Capital Formation in Underdeveloped Countries, NY: Oxford University Press. 
Ogaki, M., J.D. Ostry and C.M. Reinhart (1996), "Saving Behavior in Low- and Middle-Income Developing Countries: A Comparison", IMF Staff Papers 43(1), March: 38-71.

Olson, M. (1994), "An Intellectual Framework for Sustainable Development", mimeo, IRIS project, Department of Economics, University of Maryland, College Park, MD.

Pattillo, C. (1996), "The Impact of Uncertainty on the Investment Behavior of Ghanaian Manufacturing Sector Firms", mimeo, Centre for Study of African Economies, University of Oxford, September.

Paxson, C. (1990), "Borrowing Constraints and Portfolio Choice", Quarterly Journal of Economics 105(2), May: 535-43.

Persson, T. and G. Tabellini (1994), "Representative Democracy and Capital Taxation", Journal of Public Economics Vol 55, pp 53-70.

Pietrobelli, C. and C.Scarpa (1992), "Inducing Efficiency in the Use of Foreign Aid: The Case for Incentive Mechanisms", Journal of Development Studies, Vol 29, pp. 72-92.

Ramey, G. and V. A. Ramey (1995), "Cross-Country Evidence on the Link Between Volatility and Growth", American Economic Growth Vol 85, pp. 1138-51.

Ravenhill, J., ed (1986), Africa in Economic Crisis, New York: Columbia University Press.

Rodrik, D. (1989), "Credibility of Trade Reform: a Policymaker's Guide", The World Economy, March.

Rodrik, D. (1991), "Policy Uncertainty and Private Investment in Developing Countries", Journal of Development Economics Vol 36, pp. 229-42.

Rodrik, D. and R. Zeckhauser (1987), "The Dilemma of Government Responsiveness", Kennedy School of Government Discussion Paper No. 161, Cambridge Mass.

Sachs, J. (1996), "Growth in Africa: It Can be Done", The Economist, London, 29 June.

Sachs, J. and A. Warner (1995), "Economic Reform and the Process of Globalization", Brookings Papers on Economic Activity pp. 1-95.

Sandbrook, R (1986), "The State and Economic Stagnation in Tropical Africa", World Development Vol 14, pp. 319-32. 
Sandmo, A (1985), "The Effects of Taxation on Savings and Risk Taking", chapter 6 in A.J. Auerbach and M. Feldstein, eds, Handbook of Public Economics, Vol 1. Amsterdam:

North-Holland.

Solow, R. (1956), "A Contribution to the Theory of Economic Growth", Quarterly Journal of Economics, Vol 70, pp. 65-94.

Soskice, D., R.H. Bates and D. Epstein (1992), "Ambition and Constraint: The Stabilizing Role of Institutions", Journal of Law Economics and Organization Vol 8, pp. 547-60.

Svensson, J. (1995), "When is Foreign Aid Policy Credible? Aid Dependence and Conditionality", mimeo, Institute for International Economics Studies, Stockholm.

White, H. (1992), "The Macroeconomic Impact of Development Aid: A Critical Survey", Journal of Development Studies; 28(2), January, pp. 163-240.

Widner, J.A., ed (1994), Economic Change and Political Liberalization in Sub-Saharan Africa. Johns Hopkins University Press, Baltimore.

Williamson, J. (1995), "How East Asia turned to Exporting", mimeo, Institute for International Economics.

World Bank (1989), From Crisis to Sustainable Development: Long Term Perspective Study, Oxford, Oxford University Press.

World Bank (1994), Adjustment in Africa: Reforms, Results and the Road Ahead, Oxford, Oxford University Press. 
Policy Research Worming Papar Sentes

\begin{tabular}{|c|c|c|c|c|}
\hline & THE & Buthor & Date & $\begin{array}{l}\text { Contact } \\
\text { for paper }\end{array}$ \\
\hline WPS1869 & Risk Reducation and Public spending & $\begin{array}{l}\text { Shantayanan Devarajan } \\
\text { Jeffrey } 8 \text {. Hammer }\end{array}$ & January 1898 & $\begin{array}{l}\text { C. Bernardo } \\
3+48\end{array}$ \\
\hline WPS1870 & $\begin{array}{l}\text { The Evolution of Poverty and } \\
\text { Inequatity in Indian Villages }\end{array}$ & $\begin{array}{l}\text { Faji Jayaraman } \\
\text { Peter Lanjouw }\end{array}$ & January 1998 & $\begin{array}{l}\text { P. Lanjouw } \\
34529\end{array}$ \\
\hline WPS1871 & $\begin{array}{l}\text { Juss How Big Is Global Production } \\
\text { Sharing? }\end{array}$ & Alexander I. Yeats & January 1998 & $\begin{array}{l}\text { L. Tabada } \\
36806\end{array}$ \\
\hline WPS1872 & $\begin{array}{l}\text { How hagration into the Central } \\
\text { African Economic and Monetany } \\
\text { Community Affects Camercon's } \\
\text { Economy: General Equilbrium } \\
\text { Estimates }\end{array}$ & $\begin{array}{l}\text { Ferdinand Bakoup } \\
\text { David Tarr }\end{array}$ & January 1938 & $\begin{array}{l}\text { L. Tabada } \\
36896\end{array}$ \\
\hline WPS 1873 & $\begin{array}{l}\text { Wage Misaligrment in CFA Countries } \\
\text { Are Labor Market Policies to Biame? }\end{array}$ & Martin Rama & January 1998 & $\begin{array}{l}\text { S. Fallon } \\
\text { s8009 }\end{array}$ \\
\hline WPS1874 & $\begin{array}{l}\text { Health Policy in Poor Countries: } \\
\text { Weak Links in the Chain }\end{array}$ & $\begin{array}{l}\text { Deon Filmer } \\
\text { Jeffry Hammer } \\
\text { Lant Pritchet }\end{array}$ & January 1998 & $\begin{array}{l}\text { S. Fällon } \\
38009\end{array}$ \\
\hline WPS1875 & $\begin{array}{l}\text { How Deposit insurance Affects } \\
\text { Finencia Depth (A Cross-County } \\
\text { Analysis) }\end{array}$ & Robert Cull & Januery 1998 & $\begin{array}{l}\text { P. Sintim-Aboagye } \\
37044\end{array}$ \\
\hline WPSI876 & $\begin{array}{l}\text { Industrial Polution in Economic } \\
\text { Devslopment (Kuznets Revisited) }\end{array}$ & $\begin{array}{l}\text { Hemamala Hertige } \\
\text { Muthukumara Mani } \\
\text { David Wheeler }\end{array}$ & January 1998 & $\begin{array}{l}\text { D. Whesler } \\
3340 \text { i }\end{array}$ \\
\hline WPS1877 & $\begin{array}{l}\text { What improves Environmental } \\
\text { Pertormance? Evidence from } \\
\text { Mexican Industry }\end{array}$ & $\begin{array}{l}\text { Susmita Dasgupte } \\
\text { Hemamala Hettige } \\
\text { David Wheeler }\end{array}$ & January 1998 & $\begin{array}{l}\text { D. Wheeler } \\
33401\end{array}$ \\
\hline MPS1878 & $\begin{array}{l}\text { Searching for Sustainabie } \\
\text { Microfnance: A Review of Five } \\
\text { Indonesian Initiatves }\end{array}$ & R. Marisol Ravicz & February 1998 & $\begin{array}{l}\text { M. Ravicz } \\
85582\end{array}$ \\
\hline WPS1879 & $\begin{array}{l}\text { Relative prices and infiation in } \\
\text { Poland, 1989-97: The Special Role } \\
\text { of Administered Price increases }\end{array}$ & Przemyslaw Wozniak & February 1998 & $\begin{array}{l}\text { L. Barbone } \\
32556\end{array}$ \\
\hline WPS1880 & Foreign Aid and Rent-Seeking & Jakob Svensson & February 1998 & $\begin{array}{l}\text { R. Martin } \\
39065\end{array}$ \\
\hline WPS1881 & $\begin{array}{l}\text { The Asian Miracie and Modarn } \\
\text { Growh Theory }\end{array}$ & $\begin{array}{l}\text { Richard R. Nelson } \\
\text { Howard Pack }\end{array}$ & February 1998 & $\begin{array}{l}\text { C. Bernardo } \\
31148\end{array}$ \\
\hline WPS1882 & $\begin{array}{l}\text { Interretional Resource Transfer and } \\
\text { Economic Growth in Indonesia }\end{array}$ & Toshihiko Kawagoe & February 1998 & $\begin{array}{l}\text { R. Martin } \\
39065\end{array}$ \\
\hline
\end{tabular}




\section{Policy Research Working Paper Series}

Title Author Date

WPS1883 Intersectoral Resource Allocation and Fumihide Takeuchi Its Impact on Economic Development Takehiko Hagino in the Philippines

WPS1884 Fiscal Aspects of Evolving Federations: Issues for Policy and Research
Contact for paper

February 1998

K. Labrie 31001

February 1998

C. Bernardo 31148 